\title{
CORPORATE TAXATION AND MULTINATIONAL ACTIVITY
}

\author{
PETER EGGER \\ SIMON LORETZ \\ MiCHAEL PFAFFERMAYR \\ HANNES WINNER
}

\section{CESIFO WORKING PAPER NO. 1773}

Category 1: Public FinAnCE

AUGUST 2006

Presented at CESifo Area Conference on Global EConomy, April 2006

An electronic version of the paper may be downloaded

- from the SSRN website:

- from the RePEc website:

wWw.SSRN.com

- from the CESifo website:

www.RePEc.org

www.CESifo-group.de 


\title{
CORPORATE TAXATION AND MULTINATIONAL ACTIVITY
}

\begin{abstract}
This paper assesses the impact of corporate taxation on multinational activity. A numerically solvable general equilibrium model of trade and multinational firms is used to incorporate the following components of corporate taxation: parent and host country statutory corporate tax rates, withholding tax rates, and parent and host country depreciation allowances. We account for their differential impact under alternative methods of double taxation relief (i.e., credit, exemption, and deduction). The hypotheses regarding the effects of changes in the tax parameters are investigated in a panel of bilateral OECD outbound stocks of foreign direct investment (FDI) from 1991 to 2002. For this, we compile annual information on taxation to construct the largest existing panel of tax parameters at the bilateral level based on national tax law and bilateral tax treaties. Our findings indicate that the parent country's statutory corporate tax rate tends to foster outward FDI, whereas the host country's statutory corporate and withholding tax rates are negatively associated with outward FDI. Depreciation allowances exert a significant impact on FDI, as hypothesized.
\end{abstract}

JEL Code: H25, H73, F21, F23, C33.

Keywords: corporate taxation, foreign, direct investment, panel econometrics.

Peter Egger

Ifo Institute for Economic Research at the University of Munich

Poschingerstr. 5

81679 Munich

Germany

egger@ifo.de

Michael Pfaffermayr

Department of Economics and Statistics

University of Innsbruck

Universitaetsstr. 15

6020 Innsbruck

Austria

Michael.Pfaffermayr@uibk.ac.at
Simon Loretz

Department of Economics and Statistics

University of Innsbruck

Universitaetsstr. 15

6020 Innsbruck

Austria

Simon.Loretz@uibk.ac.at

Hannes Winner

Department of Economics and Statistics

University of Innsbruck

Universitaetsstr. 15

6020 Innsbruck

Austria

Hannes.Winner@uibk.ac.at 


\section{Introduction}

What are the expected effects of parent and host country parameters of taxation (statutory corporate and withholding tax rates, and the definition of the tax base) on bilateral multinational activity in general equilibrium under alternative methods of double taxation relief? What is their impact on bilateral stocks of foreign direct investment (FDI) in an empirical application? These issues are of obvious importance to policy makers. Yet, existing research does not provide an encompassing answer to these questions, as will be illustrated in detail below.

The importance of relying on general equilibrium models to derive the hypotheses regarding the impact of taxation on FDI has been pointed out by Hines (1997, p. 418):

"In the absence of a complete general equilibrium model, it is impossible to predict with certainty the impact of tax changes on capital demand throughout a multinational firm."

This paper analyzes the relationship between taxation and FDI in a knowledge-capital general equilibrium model of multinational enterprises (MNEs; see Markusen, 1997, 2002). This framework seems especially suited for studying the role of corporate taxation on FDI, since it has become the workhorse model of numerous recent empirical studies on the determinants of bilateral multinational activity (e.g., Carr, Markusen, and Maskus, 2001; Markusen and Maskus, 2002; Blonigen, Davies, and Head, 2003; Braconier, Norbäck, and Urban, 2005). Controlling for the most important endowmentrelated and trade and investment impediment-related determinants of FDI, we analyze the role of parent and host country parameters of taxation under alternative methods of double taxation relief. The model enables us to predict the sign of the effect of an increase in each parameter of taxation on multinational activity, separately. One particular advantage of this general equilibrium model is that taxation does not only affect the extent of multinational activity (as, e.g., in Devereux and Hubbard, 2003, and in Devereux and Lockwood, 2006), but even the configuration of plants and the integration strategies of firms in equilibrium.

Based on the insights of the theoretical model we use parent and host statutory country corporate tax rates, withholding tax rates, (net present values of) parent and host country depreciation allowances, and information about the underlying method of double taxation relief (i.e., credit, exemption, and deduction) in the empirical exercise. We collect annual data from national tax codes 
and bilateral double tax treaties for 26 OECD countries over the period 1991 to 2002. Accordingly, the time-variant tax components vary at the parent-to-host country-pair rather than the host country (unilateral) level. Overall, we obtain about 8000 data points for each bilateral tax component. To the best of our knowledge, this represents the largest existing panel data set of tax components. We assess the impact of all tax parameters separately on real bilateral outbound FDI stocks. The majority of the estimated parameter signs of the taxation variables is in accordance with the theoretical hypotheses. An omission of withholding tax rates and depreciation allowances in empirical specifications seems to ignore important dimensions of taxation and likely leads to biased estimates of the pure corporate tax effect.

The remainder of the paper is organized as follows. Section 2 provides a brief review of the existing literature. Section 3 presents a Markusen-type knowledge-capital model of trade and multinational firms, which accounts for the mentioned parameters of taxation and the methods of double taxation relief. Section 4 discusses the major testable hypotheses relating to the parameters of taxation. Section 5 describes the empirical specification. Section 6 presents the empirical findings and provides a sensitivity analysis. Section 7 concludes with a summary of the most important findings.

\section{Previous research}

Under which conditions and to which extent corporate taxes influence a firm's location and production decisions is lively debated, not only among policy makers but also among researchers (see Hines, 1997, 1999; Gresik, 2001; Devereux, 2006, for comprehensive surveys). If firms cannot arbitrarily shift their profits abroad, taxes reduce their after-tax profits and this, in turn, affects both the location and the volume of FDI. Then, a high tax burden in a host country represents an impediment to its inbound FDI, even if its effect is partly offset to the extent that governments use tax revenues to reduce investment costs. In fact, this reasoning may explain why several industrialized countries have recently reduced their corporate tax rates. ${ }^{1}$ For instance, in the Western Euro-

\footnotetext{
${ }^{1}$ Within the OECD, the statutory corporate tax rate (excluding local corporate income taxes) fell by 15 percent between 2000 and 2005, where the strongest reductions took place in Austria (2005, from 34 to 25 percent), Belgium (2005, from 39 to 33 percent), Canada (several reductions 2000-2005, from 28 to 21 percent), Germany (2001, from 40 to 25 percent), Iceland (2002, from 30 to 18 percent), Ireland (several reductions 2000-2005, from 24 to 12.5 percent) and Luxembourg (2002, from 30 to 22 percent). Among the Eastern European members, the lowest levels of corporate tax rates amount to 16 percent (Hungary, since 2004) and 19 percent (Poland and Slovak Republic, since 2004), respectively.
} 
pean economies corporate tax rates have been reduced in response to the much lower tax rates in Central and Eastern Europe.

Empirical evidence tends to confirm the presumption that taxation is decisive for production and location decisions of MNEs. The bulk of results is available for the U.S. (see Hines, 1997, for an excellent overview). Three strands of the literature can be distinguished here. One of them analyzes the impact of U.S. corporate tax rates on inbound FDI (see, e.g., Hartman, 1984; Bartik, 1985; Coughlin, Terza, and Arromdee, 1991; Head, Ries, and Swenson, 1999). A second line of research studies the effects of host country taxes on U.S. outbound FDI (see Grubert and Mutti, 1991, 2000; Hines and Rice, 1994; Devereux and Griffith, 1998; Grubert and Slemrod, 1998; Altshuler, Grubert, and Newlon, 2001; Mutti and Grubert, 2004; Desai, Foley, and Hines, 2005). A third strand of work considers both parent and host country taxation by additionally accounting for the role of the underlying method of double taxation relief, i.e., whether (repatriated) profits of foreign affiliates are taxed on a territorial or a worldwide basis in the country where the headquarters are located (see Slemrod, 1990; Shah and Slemrod, 1991; Cummins and Hubbard, 1995; Swenson, 1994, 2001; Hines, 1996). In general, the U.S. evidence reveals that inbound FDI is negatively affected by the U.S. tax burden, ${ }^{2}$ and U.S. outbound FDI is positively (negatively) associated with domestic (host country) tax rates. Although one would expect that the impact of tax rates differs between countries applying the credit and exemption method (see, e.g., Slemrod, 1990), ${ }^{3}$ there is no clear-cut empirical support for this view.

Only a few studies consider a broader set of country-pairs. Devereux and Freeman (1995), using bilateral FDI flows between seven countries (including the U.S.) from 1984 to 1989 and referring to a cost-of-capital concept of taxation, find that a firm's choice between domestic and foreign investment as such is not influenced by taxation. However, given that a firm has decided to invest abroad, taxation is decisive for where the investment takes place. The results of Bénassy-Quéré, Fontagné, and Lahrèche-Révil (2005), relying on bilateral FDI flows among 11 OECD countries over the period 1984-2000 and using statutory corporate tax rates as well as (forward-looking) effective marginal (EMTR)

\footnotetext{
${ }^{2}$ One notable exception is Swenson (1994), who finds that the increased after-tax cost of capital after the Tax Reform Act 1986 induced an increase in U.S. inbound FDI. The underlying reason is that the broadening of the tax base raised the attractiveness of U.S. assets for foreign investors whose parent countries allowed a tax credit against taxes abroad (see Scholes and Wolfson, 1990, for a theoretical foundation of this argument).

${ }^{3}$ Under the credit method, foreign-earned profits are taxed both in the parent and the host country, but the foreign taxes are deductible from the domestic tax liability. Under the exemption method, by way of contrast, foreign-earned profits are only taxed abroad.
} 
and average tax rates $(E A T R)$ as published in Devereux, Griffith, and Klemm (2002), indicate a significant role of tax differentials for foreign plant location. Razin, Rubinstein, and Sadka (2005) point out that statutory tax rates affect FDI flows in two ways. First, they determine whether it is profitable for any firm to invest in a particular host country at all (sample selection). Second, given that some investment takes place, they affect the magnitude of these investments. Razin, Rubinstein, and Sadka (2005) find supportive evidence for these hypotheses in a panel of bilateral OECD FDI flows. Regarding investment flows to Central and Eastern European countries, Carstensen and Toubal (2004) observe a significant negative impact of the difference in host and parent country statutory corporate tax rates on inward FDI. ${ }^{4}$

Overall, previous empirical research is characterized by two features. First, most of the existing literature considers the parent and/or host country tax rate or composite measures of tax burden (e.g., forward- or backward-looking effective tax rates). The former approach ignores important tax-related determinants of FDI, such as depreciation allowances or host country withholding taxes (see Clark, 2000; OECD, 2001). The problem with the latter approach is that it is difficult to draw strong conclusions about the 'composite' impact of the tax components through effective tax rates on MNE activity. ${ }^{5}$ In particular, our theoretical hypotheses shed light on the fact that some of the components of effective tax rates exert a non-monotonic effect on FDI, where the sign of the impact depends on the relative prevalence of multinational versus national firms.

Second, many of the existing applications tend to rely on an eclectic approach to specifying empirical FDI equations. In this regard, Hines (1999, p. 311) emphasizes that

"[O]ne of the difficulties facing all cross-sectional studies of FDI location is the inevitable omission of many important determinants of FDI that may be correlated with tax rates and therefore bias estimation of tax elasticities."

\footnotetext{
${ }^{4}$ De Mooij and Ederveen (2003), performing a meta-analysis based on 25 empirical studies on FDI and taxation, estimate a (median) tax rate elasticity of -3.3 . Focusing on U.S. studies, Hines (1997) reports a tax rate elasticity of approximately -0.6.

${ }^{5}$ Basically, effective tax rates are an aggregate measure of company tax burden, i.e., the same level of the effective tax rate may be a result of different combinations of its components. Hence, an increase of effective tax rates may be due to entirely different changes in the underlying components. More importantly, it can be shown that in a general equilibrium model of trade and multinationals as the one applied below, effective (marginal and average) tax rates change across endowment configurations, even if the tax parameters themselves remain unchanged. Hence, effective tax rates are endogenous even for given tax rates.
} 
Of course, this argument does not advocate an empirical analysis that uses all available explanatory variables, disregarding their theoretical relevance. But rather, it makes the case for a specification of FDI capturing the most important empirical determinants consistent with theory. Following this advice, we employ an empirical specification based on a variant of the knowledge-capital model of multinational firms.

\section{A numerically solvable general equilibrium model of trade and multinational firms under corporate taxation}

Consider two economies, indexed $\{i, j\}=\{1,2\}$, and two sectors, $Z$ and $X$. $Z$ is a homogeneous (agricultural) good produced at constant returns to scale. There is a large number of varieties of (manufactures) $X$ that are imperfect substitutes as in Dixit and Stiglitz (1977).

$X$ can be produced by three types of firms. National enterprises (NEs) serve domestic consumers locally and foreign ones via exports. The corresponding number of NEs in country $i$ is denoted by $n_{i}$. Horizontal MNEs headquartered in country $i$ run a plant each at home and abroad. Hence, they serve consumers in both countries through local production and do not engage in trade. The central motives to enter as a horizontal MNE are the avoidance of trade costs and the exploitation of multi-plant economies of scale. $h_{i}$ indicates the number of horizontal MNEs headquartered in $i$. Vertical MNEs unbundle their headquarters' activities from the production process. They produce headquarters' services in the skilled labor abundant economy and locate production in the unskilled labor abundant country. They serve foreign consumers locally and domestic ones via exports from their foreign subsidiary. $v_{i}$ denotes the number of vertical MNEs headquartered in $i$.

Quantities are indexed as follows. The superscript indicates the firm type, the first subscript refers to the country where the firm is headquartered, the second one denotes the country where the variety is produced, and the third subscript labels the economy where the variety is consumed. For instance, $X_{i i j}^{n}$ is the production of manufactures produced by a single NE of $i$ in $i$ for consumers in $j$. Consider a horizontal MNE with headquarters in country $i$. Then, $X_{i j j}^{h}$ indicates this firm's production in country $j$ for consumers there. Now, focus on a vertical MNE with headquarters in $i$. Such a firm's production in country $j$ for consumers in $i$ is denoted by $X_{i j i}^{v}$. Subscripts are used in the 
same way with the homogeneous good $Z$.

\subsection{Households}

Preferences are assumed to be a Cobb-Douglas nest of the homogeneous $Z$ good and the differentiated $X$-good. The price of $Z$ serves as the numéraire. $U_{i}$ describes the utility function of a representative household in country $i$, where $\mu$ denotes the fixed expenditure share for differentiated products and $\sigma>1$ is the elasticity of substitution between differentiated product varieties:

$$
\begin{aligned}
U_{i}= & X_{i c}^{\mu}\left(Z_{i i i}+Z_{j j i}\right)^{1-\mu} \\
X_{i c} \equiv & {\left[n_{i}\left(X_{i i i}^{n}\right)^{\frac{\sigma-1}{\sigma}}+n_{j}\left(\frac{X_{j j i}^{n}}{1+\tau}\right)^{\frac{\sigma-1}{\sigma}}+h_{i}\left(X_{i i i}^{h}\right)^{\frac{\sigma-1}{\sigma}}\right.} \\
& \left.+h_{j}\left(X_{j i i}^{h}\right)^{\frac{\sigma-1}{\sigma}}+v_{i}\left(\frac{X_{i j i}^{v}}{1+\tau}\right)^{\frac{\sigma-1}{\sigma}}+v_{j}\left(X_{j i i}^{v}\right)^{\frac{\sigma-1}{\sigma}}\right]^{\frac{\sigma}{\sigma-1}} .
\end{aligned}
$$

Transportation of the differentiated $X$-good across the border is subject to iceberg transport costs $(\tau)$ for the shipment of each unit. $Z$-goods, in contrast, are costlessly tradeable.

For each firm type and location, the utility maximization of consumers yields demand for a single variety of manufactures

$$
\begin{aligned}
& X_{i i i}^{k}=\left(p_{i i i}^{k}\right)^{-\sigma} P_{i}^{\sigma-1} \mu E_{i} \quad \forall i \in\{1,2\} \wedge \quad \forall k \in\{n, h\} \\
& X_{j i i}^{k}=\left(p_{j i i}^{k}\right)^{-\sigma} P_{i}^{\sigma-1} \mu E_{i} \quad \forall i \neq j \in\{1,2\} \quad \wedge \quad \forall k \in\{h, v\} \\
& X_{i j i}^{v}=\left(p_{i j i}^{v}\right)^{-\sigma} P_{i}^{\sigma-1} \mu E_{i} \quad \forall i \neq j \in\{1,2\} \\
& X_{j j i}^{n}=\left(p_{j j i}^{n}\right)^{-\sigma} P_{i}^{\sigma-1} \mu E_{i} \quad \forall i \neq j \in\{1,2\} .
\end{aligned}
$$

$E_{i}$ represents the total expenditures of consumers in country $i$. The price index $P_{i}$ of differentiated goods consumed in country $i$ can be written as

$$
\begin{aligned}
P_{i}= & {\left[n_{i}\left(p_{i i i}^{n}\right)^{1-\sigma}+n_{j}\left(p_{j j i}^{n}\right)^{1-\sigma}+h_{i}\left(p_{i i i}^{h}\right)^{1-\sigma}\right.} \\
& \left.+h_{j}\left(p_{j i i}^{h}\right)^{1-\sigma}+v_{i}\left(p_{i j i}^{v}\right)^{1-\sigma}+v_{j}\left(p_{j i i}^{v}\right)^{1-\sigma}\right]^{\frac{1}{1-\sigma}} .
\end{aligned}
$$

Expenditures for $X$ and $Z$ are allocated as follows:

$$
X_{i c}=\frac{\mu E_{i}}{P_{i}},
$$




$$
Z_{i i i}+Z_{j j i}=(1-\mu) E_{i}
$$

\subsection{Production and labor market}

The production function for $Z$ is a CES technology being identical in both countries. It uses skilled labor $(S)$ and unskilled labor $(L)$, at a technical rate of substitution of $1 /(1-\rho)$ :

$$
Z_{i i i}+Z_{i i j}=\left[a S_{i}^{\rho}+(1-a) L_{i}^{\rho}\right]^{\frac{1}{\rho}}
$$

where $a$ is a weighting parameter. Since all firms within a country face the same homothetic technology and identical factor prices, the $Z$-sector input coefficients are identical across firms. Let $w_{S i}$ and $w_{L i}$ denote the factor rewards for skilled and unskilled labor in country $i$. Skipping the arguments, these input coefficients are determined as

$$
\begin{aligned}
& a_{L Z i}=\left(\frac{w_{L i}}{1-a}\right)^{\frac{1}{\rho-1}}\left[\left(\frac{w_{S i}^{\rho}}{a}\right)^{\frac{1}{\rho-1}}+\left(\frac{w_{L i}^{\rho}}{1-a}\right)^{\frac{1}{\rho-1}}\right]^{-\frac{1}{\rho}} \\
& a_{S Z i}=\left(\frac{w_{S i}}{a}\right)^{\frac{1}{\rho-1}}\left[\left(\frac{w_{S i}^{\rho}}{a}\right)^{\frac{1}{\rho-1}}+\left(\frac{w_{L i}^{\rho}}{1-a}\right)^{\frac{1}{\rho-1}}\right]^{-\frac{1}{\rho}} .
\end{aligned}
$$

Perfect competition in the production of the homogeneous $Z$ ensures zero profits so that unit costs satisfy

$$
a_{L Z i} w_{L i}+a_{S Z i} w_{S i} \geq 1 \quad \perp \quad Z_{i i i} \geq 0, Z_{i i j} \geq 0 \quad \forall \quad i, j \in\{1,2\},
$$

where $\perp$ indicates that at least one of the adjacent conditions has to hold with equality. Zero trade costs lead to an equalization of marginal costs across countries.

The production of manufactures $X$ uses both factors in fixed proportions (see Markusen, 2002), where $a_{L X}$ and $a_{S X}$ are the corresponding input coefficients for production. The set-up of firms in the $X$-sector requires skilled labor in order to produce firm-specific assets and blueprints as well as unskilled labor to set up plant-specific assets (production facilities). In line with the literature, we assume that fixed input requirements are highest for horizontal MNEs, lower for vertical MNEs, and lowest for NEs. Specifically, national firms need 2 units of skilled labor, while (horizontal and vertical) MNEs employ $2+\theta$ units. This accounts for the higher firm-specific fixed costs of running a multinational net- 
work. For NEs and for domestic plants of horizontal MNEs the plant-specific fixed input requirements are equal to 1 unit of unskilled labor. Setting up a plant abroad requires $1+\gamma$ units of unskilled labor, reflecting the associated fixed cost disadvantages of MNEs.

Under full employment, the factor market clearing conditions for unskilled and skilled labor in country $i$ require

$$
\begin{aligned}
L_{i} \geq & a_{L X}\left[n_{i}\left(X_{i i i}^{n}+X_{i i j}^{n}\right)+h_{i} X_{i i i}^{h}+h_{j} X_{j i i}^{h}+v_{j}\left(X_{j i i}^{v}+X_{j i j}^{v}\right)\right] \\
& +a_{L Z i}\left(Z_{i i i}+Z_{i i j}\right) \\
& +n_{i}+h_{i}+(1+\gamma)\left(h_{j}+v_{j}\right) \quad \perp \quad w_{L i} \geq 0, \\
& \\
S_{i} \geq & a_{S X}\left[n_{i}\left(X_{i i i}^{n}+X_{i i j}^{n}\right)+h_{i} X_{i i i}^{h}+h_{j} X_{j i i}^{h}+v_{j}\left(X_{j i i}^{v}+X_{j i j}^{v}\right)\right] \\
& +a_{S Z i}\left(Z_{i i i}+Z_{i i j}\right)+2 n_{i}+(2+\theta)\left(h_{i}+v_{i}\right) \quad \perp \quad w_{S i} \geq 0 .
\end{aligned}
$$

Variable unit costs for the production of an $X$-variety are given by $c_{X i}=$ $a_{S X} w_{S i}+a_{L X} w_{L i}$. Fixed costs are financed by operating profits. There is a fixed markup over variable costs, which is determined by the elasticity of substitution between varieties. Identical technologies and price elasticities of demand ensure that the domestic price of a locally produced good (the mill price) is identical in equilibrium across all firms producing there. Therefore, it is sufficient to use a single subscript for the producer prices, indicating the country of production: $p_{i} \equiv p_{i i i}^{n}=p_{i i i}^{h}=p_{j i i}^{h}=p_{j i i}^{v}$. The consumer price for varieties exported from country $i$ to $j$ is then $p_{i}(1+\tau) \equiv p_{i i j}^{n}=p_{j i j}^{v}$. Given that the demand for all varieties is positive due to our assumptions, the mill price of a variety of $X$ in $i$ is determined by

$$
p_{i}=c_{X i} \frac{\sigma}{\sigma-1} .
$$

Free entry of firms implies that after-tax profits are zero. Therefore, the corresponding zero-profit conditions determine the number of firms. NEs in $i$ face fixed costs of $F C_{i}^{n}=2 w_{S i}+w_{L i}$. After subtracting depreciation allowances, these fixed costs have to be covered by after-tax operating profits. Operating profits of NEs are subject to the domestic statutory corporate tax rate $\left(t_{i}\right)$. We denote the share of fixed costs which is deductible from the tax base by $\delta_{i}{ }^{6}$

\footnotetext{
${ }^{6}$ An alternative would be to apply depreciation allowances for variable costs additionally. However, since variable costs are not deductible at the same rate as fixed costs, we do not rely on this variant in the main text but relegate it to a sensitivity analysis. We briefly discuss the outcome of this model variant in Footnote 18, below.
} 
NEs in country $i$ exist if their fixed costs are equal to after tax profits including depreciation allowances $\left(D_{i}^{n}\right)$

$$
F C_{i}^{n} \geq \frac{p_{i}\left(X_{i i i}^{n}+X_{i i j}^{n}\right)}{\sigma}\left(1-t_{i}\right)+\underbrace{\delta_{i} t_{i}\left(2 w_{S i}+w_{L i}\right)}_{D_{i}^{n}} \quad \perp \quad n_{i} \geq 0 .
$$

The fixed costs of MNEs are $F C_{i}^{h}=(2+\theta) w_{S i}+w_{L i}+(1+\gamma) w_{L j}$ for a horizontal MNE and $F C_{i}^{v}=(2+\theta) w_{S i}+(1+\gamma) w_{L j}$ for a vertical MNE, respectively. The corresponding zero profit conditions are given by

$$
\begin{aligned}
F C_{i}^{h} \geq & \frac{p_{i} X_{i i i}^{h}\left(1-t_{i}\right)+\frac{p_{j} X_{i j j}^{h}}{\sigma}\left(1-t_{j}\right)\left(1-t_{j i}^{M}\right)}{}+\underbrace{\delta_{i} t_{i}\left(2 w_{S i}+w_{L i}\right)+\delta_{j} t_{j}\left(t_{j i}^{M}-t_{j}^{w}\right)(1+\gamma) w_{L j} j}_{D_{i i}^{h}} \\
& +\underbrace{\delta_{j} t_{j}\left(1+t_{j}^{w}\right)(1+\gamma) w_{L j}}_{D_{i j}^{h}} \perp h_{i} \geq 0 \\
F C_{i}^{v} \geq & \frac{p_{j}\left(X_{i j i}^{v}+X_{i j j}^{v}\right)}{\sigma}\left(1-t_{j}\right)\left(1-t_{j i}^{M}\right) \\
& +\underbrace{\delta_{j} t_{j}\left(t_{j i}^{M}-t_{j}^{w}\right)(1+\gamma) w_{L j}}_{D_{i i}^{v}} \\
& +\underbrace{\delta_{j} t_{j}\left(1+t_{j}^{w}\right)(1+\gamma) w_{L j}}_{D_{i j}^{v}} \perp v_{i} \geq 0,
\end{aligned}
$$

where $D_{i j}^{h}$ indicates the depreciation allowances of a horizontal MNE with headquarters in country $i$ at market $j$, and similarly for the other depreciation allowances. Our setting implicitly assumes that fixed costs are deductible only in the country where the investment takes place. We further assume that MNEs fully repatriate the profits of foreign subsidiaries to the domestic headquarters (see Hartman, 1985; and Sinn, 1993, for a discussion). In this case, operating profits of foreign affiliate firms are subject to corporate taxation in the host country $\left(t_{j}\right)$. Under repatriation, foreign-earned profits are additionally subject to withholding taxes $\left(t_{j}^{w}\right)$ and taxation at home $\left(t_{j i}^{M}\right)$, where the first subscript in $t_{j i}^{M}$ denotes the origin and the latter the destination of the dividend flow. Hence, if double taxation is not alleviated unilaterally or bilaterally (via tax treaties), foreign affiliate income is exposed to double taxation. The extent to which double taxation occurs depends on the method of double taxation relief 
(Alworth, 1988, provides a detailed discussion).$^{7}$

$$
\begin{aligned}
& t_{j i}^{M}=t_{j}^{w} \quad \text { (exemption) } \\
& =\max \left[\frac{t_{i}-t_{j}}{1-t_{j}}, t_{j}^{w}\right] \quad \text { (credit) } \\
& =t_{i}\left(1-t_{j}^{w}\right)+t_{j}^{w} \quad \text { (deduction) }
\end{aligned}
$$

All production factors are owned by the households, so that consumer income is determined by the sum of factor rewards in country $i\left(w_{S i} S_{i}+w_{L i} L_{i}\right)$ plus the eventual transfers of tax revenues to them. Below, we discuss two modes of public spending of tax revenues, where only one of them involves such transfers.

\subsection{Public sector}

The only source of tax revenues are taxes on operating profits of firms. Hence, tax revenues for country $i$ can be summarized as

$$
\begin{aligned}
G_{i}= & n_{i}\left[\left(X_{i i i}^{n}+X_{i i j}^{n}\right) \frac{p_{i}}{\sigma} t_{i}-D_{i}^{n}\right] \\
& +h_{i}\left[X_{i i i}^{h} \frac{p_{i}}{\sigma} t_{i}+X_{i j j}^{h} \frac{p_{j}}{\sigma}\left(1-t_{j}\right)\left(t_{j i}^{M}-t_{j}^{w}\right)-D_{i i}^{h}\right] \\
& +v_{i}\left[\left(X_{i j j}^{v}+X_{i j i}^{v}\right) \frac{p_{j}}{\sigma}\left(1-t_{j}\right)\left(t_{j i}^{M}-t_{j}^{w}\right)-D_{i i}^{v}\right] \\
& +h_{j}\left[X_{j i i}^{h} \frac{p_{i}}{\sigma}\left(t_{i}-t_{i} t_{i}^{w}+t_{i}^{w}\right)-D_{j i}^{h}\right] \\
& +v_{j}\left[\left(X_{j i i}^{v}+X_{j i j}^{v}\right) \frac{p_{j}}{\sigma}\left(t_{i}-t_{i} t_{i}^{w}+t_{i}^{w}\right)-D_{j i}^{v}\right] .
\end{aligned}
$$

Tax revenues are either used to finance a lump-sum transfer to consumers or to provide public infrastructure to the firms to lower their fixed input requirements (see Kellenberg, 2003, for a treatment of infrastructure in a model with MNEs). In case of lump-sum transfers, the gross national income of country $i$ $\left(E_{i}\right)$ includes the tax revenues collected by its government. In case of public infrastructure provision, no such transfers occur and the gross national income equals total factor income in $i$. We assume that one unit of public infrastructure needs one unit of skilled labor and one unit of unskilled labor. ${ }^{8}$ Accordingly, public infrastructure $\left(I_{i}\right)$ in country $i$ equals

\footnotetext{
${ }^{7}$ See Bond and Samuleson (1989), Janeba (1995), and Davies (2003) for a theoretical analysis on the effects of the methods of double taxation relief on the volume of foreign investment. Davies (2004) provides a survey.

${ }^{8}$ This guarantees that the production of public infrastructure as such only induces minor effects on relative factor prices of skilled and unskilled labor.
} 


$$
I_{i}=\frac{G_{i}}{w_{S i}+w_{L i}} .
$$

Under the assumption that public infrastructure reduces the fixed factor requirement of firms headquartered in a given country, the fixed costs of setting up a national firm in country $i$ are

$$
F C_{i}^{n}=\frac{2 w_{S i}+w_{L i}}{\left(I_{i}+1\right)^{\beta}}
$$

where $\beta>0$ is a scaling parameter. Similarly, the fixed costs for horizontal and vertical multinationals are then reduced by the public infrastructure in the relevant country

$$
\begin{aligned}
F C_{i}^{h} & =\frac{(2+\theta) w_{S i}+w_{L i}}{\left(I_{i}+1\right)^{\beta}}+\frac{(1+\gamma) w_{L j}}{\left(I_{j}+1\right)^{\beta}}, \\
F C_{i}^{v} & =\frac{(2+\theta) w_{S i}}{\left(I_{i}+1\right)^{\beta}}+\frac{(1+\gamma) w_{L j}}{\left(I_{j}+1\right)^{\beta}} .
\end{aligned}
$$

\subsection{Model parameterization}

Due to the non-linearities and the numerous possible corner solutions, an analytical solution of the model is infeasible (see Markusen and Venables, 1998, 2000; Markusen, 2002). Therefore, we derive the empirically testable hypotheses of interest by means of numerical simulation, using the following parameter values. World factor endowments are set at $L=200$ and $K=50 . a=0.9$ for the skilled labor coefficient in the CES technology of $Z$. The production of the differentiated $X$-good is relatively more skilled labor intensive with fixed input coefficient of $a_{L X}=0.75$ and $a_{S X}=0.25$ (see Markusen, 2002). We parameterize the additional effort of transferring knowledge abroad with $\theta=0.1$ and the additional resources required for setting up a plant abroad with $\gamma=0.1$. According to the United Nation's World Trade Database, the share of manufacturing goods trade in the 1990s is about 70 to 80 percent of total trade. Therefore, we assume an expenditure share for manufactures of $\mu=0.8$. We consider $\sigma=4$ as value for the elasticity of substitution, which is close to the one usually applied in the knowledge-capital literature (see Markusen, 2002). Trade costs are assumed to be high with $\tau=0.25$ being in line with Carr, Markusen, and Maskus (2001). Finally, the elasticity of substitution in the production of the homogeneous good is $(1 /(1-\rho))=3$.

Concerning the public sector, we initially set the corporate tax rates sym- 
metrically at $t_{i}=t_{j}=0.3$, which roughly resembles the average corporate tax rate in the OECD countries in 2004. We account for the fact that bilateral tax treaties prevail among the countries of interest and set the withholding tax rate at a low level, $t_{i}^{w}=t_{j}^{w}=0.05$. We assume that about 20 percent of fixed costs are tax deductible so that $\delta=0.2 .^{9}$ In the case where tax revenues are used to finance public infrastructure, the scaling parameter determining the relative importance of public infrastructure is set at $\beta=0.1$.

\section{Simulation results and hypotheses}

Without corporate taxation (i.e., setting all parameters of taxation to zero) the chosen calibration of the model leads to a pattern of affiliate production which is virtually identical to the one in Carr, Markusen, and Maskus (2001) and in Markusen and Maskus (2002). Below, we measure foreign affiliate activity as the share of outbound affiliate production of country $i$ (defined as $\left(h_{i}+v_{i}\right) X_{i j j}+$ $\left.v_{i} X_{i j i}\right)$ in the world production of $X$. Horizontal multinational firms prevail, if country size and relative factor endowments are not too different. Vertical multinationals come into existence only, if relative factor endowment differences (i.e., production cost differences) are large enough. Higher trade costs (foreign plant set-up costs) discourage NEs (MNEs).

Figure 1 displays foreign affiliate production in an Edgeworth box with factor endowments on the axes for the benchmark case without corporate taxation. First, consider factor endowments along the main diagonal indicating countries with identical relative factor endowments. Here, NEs and horizontal MNEs prevail, and foreign affiliate production is higher the more similar the countries are in size. Second, moving from the center towards the North-Western corner implies larger differences in relative factor endowments, inducing an increase in foreign affiliate production by vertical MNEs, all else equal. In the subsequent analysis we introduce corporate taxation and primarily focus on the case where tax revenues are used to finance public infrastructure. However, in qualitative terms, the effects are similar for lump-sum transfers. The reason is that corporate taxation affects the equilibrium plant configuration even if tax revenues are redistributed in a lump-sum fashion. ${ }^{10}$

\footnotetext{
${ }^{9}$ In our empirical analysis below, we measure tax base reducing allowances by depreciation rates including first-year extra depreciations (see Devereux and Griffith, 1999, 2003). The net present value of depreciation allowances for tax purposes is about 30 percent higher than the assumed depreciation rate in the model simulation. The means of the periodical depreciation rates in the sample are about 22 percent (machinery) and 5 percent (buildings), respectively.

${ }^{10}$ Figures and other results for the lump-sum transfer case are available from the authors
} 


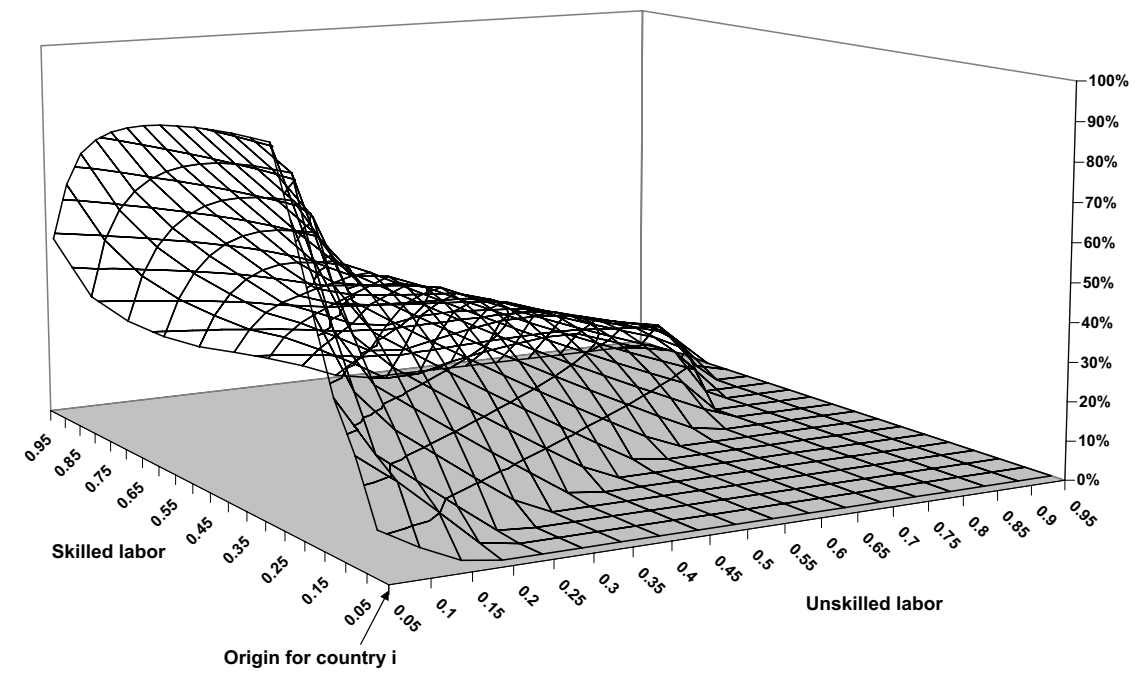

Figure 1: Share of affiliate production without corporate taxation

Figure 2 displays the share of foreign affiliate production under the exemption or credit method. ${ }^{11}$ In this case, multinational activity is affected only to a minor extent by corporate taxation (see the small differences between Figures 1 and 2). ${ }^{12}$ Only for small countries near the main diagonal we observe less foreign affiliate activity of horizontal MNEs, resulting from the additional tax burden for MNEs due to withholding taxes. The foreign affiliate activities of vertical MNEs located in the North-Western corner of the Edgeworth box are more or less unaffected by profit taxation.

Compared to tax credit and exemption methods the deduction method is associated with a higher tax burden on MNEs. Accordingly, the distortion of multinational activity induced by corporate taxation becomes more evident under deduction. Figure 3 illustrates that the foreign activity of horizontal MNEs is significantly reduced as compared to the case of the exemption and the credit method, especially for small countries. ${ }^{13}$ In small economies, firms choose serving the foreign markets via exports since double taxation reduces foreign affiliate profits required to cover the fixed costs abroad. However, if the home country is large enough and tax revenue is used to finance public infrastructure, horizontal MNEs come into existence even under deduction. In this case, tax

\footnotetext{
upon request but are suppressed here for the sake of brevity.

${ }^{11}$ Note that we assume symmetric tax rates in the initial equilibrium so that the exemption and the credit methods have an identical effect.

${ }^{12}$ See also Figure 5 in the Appendix, displaying the difference between the surfaces in Figure 2 and Figure 1.

${ }^{13}$ This can be also seen from the differential plot in the Appendix (Figure 6).
} 


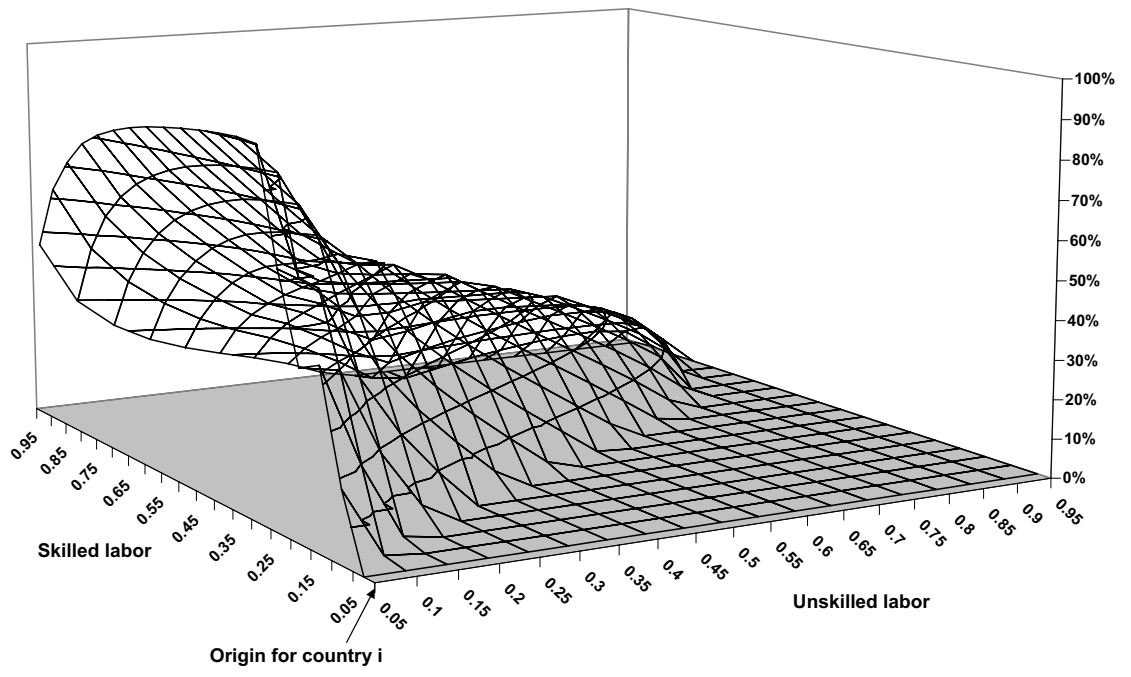

Figure 2: Share of affiliate production with exemption or credit method $\left(t_{i}=t_{j}=0.3 ; t_{i}^{w}=t_{j}^{w}=0.05 ; \delta_{i}=\delta_{j}=0.2 ;\right.$ public infrastructure investments $)$

revenues are high enough to finance public infrastructure, reducing fixed plant setup costs to compensate the disadvantages of double taxation. Again, the production decisions of vertical MNEs are nearly unaffected by double taxation.

In the following, we focus on four factor endowment configurations within the Edgeworth box to derive the effects of the considered tax parameters on MNE activity. ${ }^{14}$ For each of these endowment points and each method of double taxation relief (credit, exemption, and deduction), we compare the foreign affiliate production in the reference case as described in Section 3.4 with a counterfactual where the taxation parameters of interest are increased by one percentage point, one at a time. Our parameterization (symmetric tax rates) is not suitable to illustrate the differential effects of taxation under the credit method as compared to exemption. Therefore, we allow initial tax rate differentials between domestic and foreign countries in alternative scenarios. The results are summarized in Table 1.

We consider the following endowment configurations. First, one where country $i$ is small but the relative factor endowments are identical across countries at $L_{i} /\left(L_{i}+L_{j}\right)=S_{i} /\left(S_{i}+S_{j}\right)=0.15$. There, country $i$ 's foreign affiliate production is small, amounting to only 1.65 percent of the world production of $X$ under tax credit or exemption (there is no MNE activity under deduction at this endowment configuration). Second, at zero relative factor endowment differences,

\footnotetext{
${ }^{14}$ We do not consider any impact of taxation on outbound MNE activity of an unskilled labor abundant economy, since such an economy does not run foreign affiliates.
} 


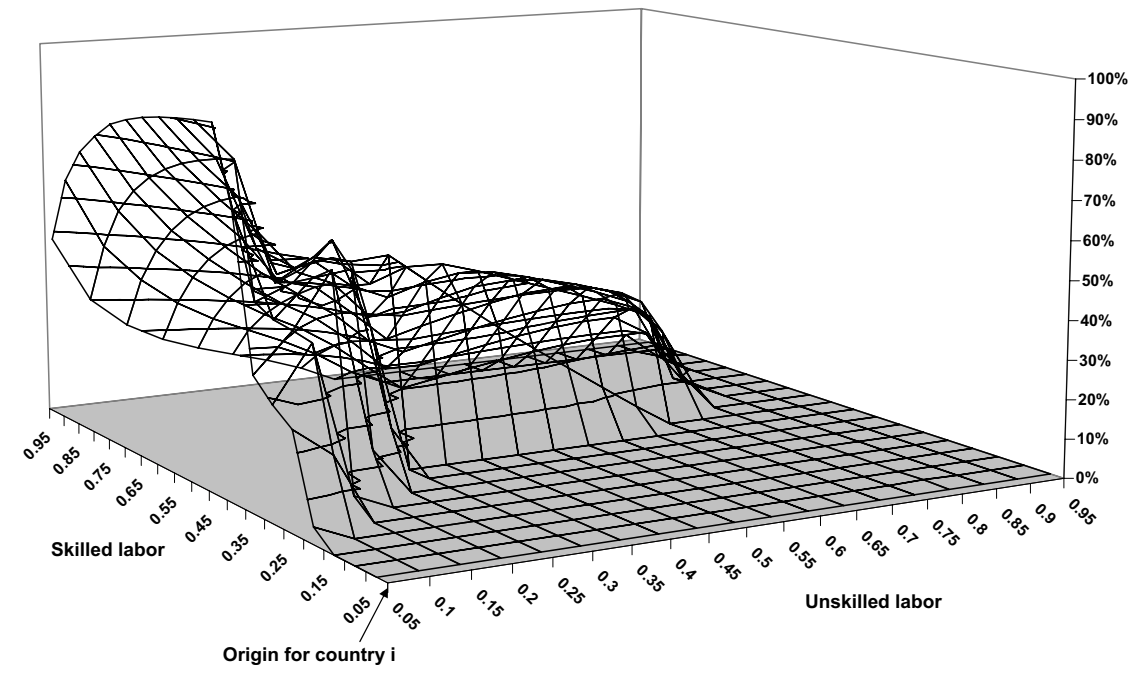

Figure 3: Share of affiliate production with deduction method $\left(t_{i}=t_{j}=0.3\right.$; $t_{i}^{w}=t_{j}^{w}=0.05 ; \delta_{i}=\delta_{j}=0.2$; public infrastructure investments)

$L_{i} /\left(L_{i}+L_{j}\right)=S_{i} /\left(S_{i}+S_{j}\right)=0.85$, country $i$ is large relative to $j$. Still, its MNE activity is relatively small. Country $i$ 's foreign affiliate production amounts to 14.98 percent of the world production of $X$ under tax credit or exemption and to 8.07 percent under deduction, respectively. Third, in the center of the Edgeworth box the two countries are identical in size and relative factor endowments with $L_{i} /\left(L_{i}+L_{j}\right)=L_{j} /\left(L_{i}+L_{j}\right)=S_{i} /\left(S_{i}+S_{j}\right)=S_{j} /\left(S_{i}+S_{j}\right)=0.5$. Therefore, exactly 50 percent of a horizontal MNE's production takes place in its foreign subsidiary. Vertical MNEs do not exist in this case. The foreign affiliate production of country $i$ accounts for 25 percent of the overall production of $X$ by NEs and MNEs, irrespective of the applied method of double taxation relief. Finally, consider an endowment allocation where country $i$ is skilled labor abundant with $L_{i} /\left(L_{i}+L_{j}\right)=0.15$ and $S_{i} /\left(S_{i}+S_{j}\right)=0.85$. At this configuration, it headquarters mainly vertical MNEs that exploit the gains from comparative advantage, and 45.26 (45.94) percent of the production of $X$ are due to country $i$ 's foreign subsidiary activity under credit or exemption (deduction). Table 1 also provides a summary of the effects of a one percent increase in each of the parameters of taxation on country $i$ 's MNE activity, separately.

The impact of statutory corporate tax rates on MNE activity: Under the exemption method, any increase in the parent country tax rate stimulates 


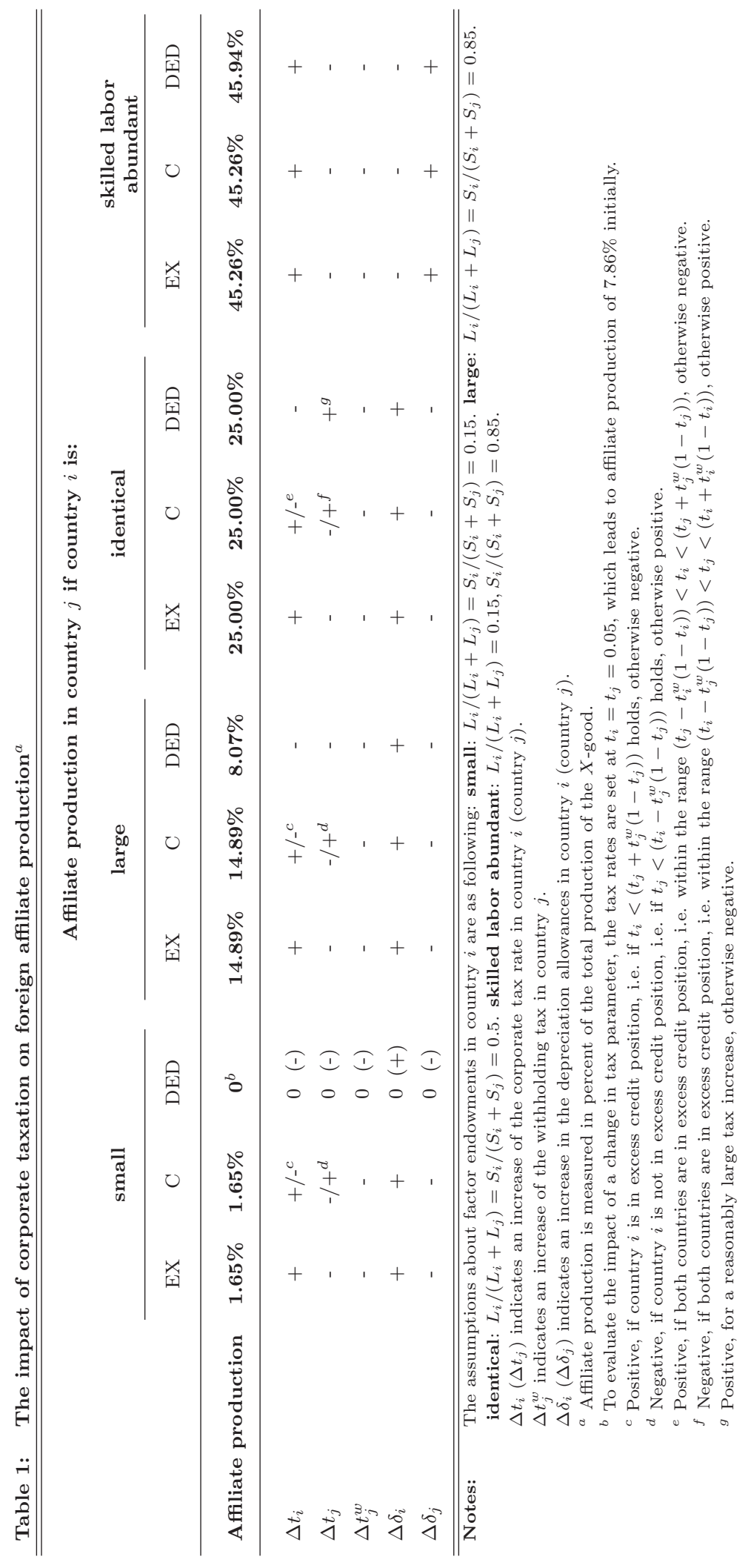


foreign affiliate production. ${ }^{15}$ The reason for the positive nexus of parent country tax rates and outbound MNE activity is that the change in its tax rate only affects domestic production. For similar reasons, a higher tax rate in the host country reduces affiliate production there. Hence, the predicted effect of an increase in parent (host) country corporate tax rates on a country's outbound MNE activity is positive (negative) under exemption.

With the credit method, the effects of corporate tax rates are ambiguous if horizontal MNE activity prevails (i.e., the factor endowment differences are not important; see the first three endowment configurations under tax credits in Table 1). As becomes apparent from (16), the impact of a tax increase depends on the differential between domestic and foreign corporate tax rates. If the parent country is in an excess credit position (i.e., its corporate tax rate is lower than the host country tax burden; see footnote $c$ in Table 1) the effect of the parent country's tax increase is the same as under the exemption method. An increase in the statutory tax rate of the parent country fosters its foreign affiliate production. The tax increase, by contrast, applies to operating profits of foreign affiliates if the parent tax rate is equal to or higher than the host tax burden. This reduces foreign affiliate activities of horizontal MNEs, while rendering the domestic production of host country owned firms better off. ${ }^{16}$ For similar reasons, an increase in the host country's corporate tax rate induces the opposite effect.

With a deduction system, an increase in the corporate tax rate reduces MNE activities in both countries, ${ }^{17}$ with two exceptions. First, if both countries are identical, an increase in the host country corporate tax rate fosters foreign affiliate activity there, as long as the tax burden becomes not prohibitively high. Although the tax burden is increased for all (domestic and foreign) MNEs, the foreign ones are even more exposed to double taxation. Second, for skilled labor abundant parent countries, an increase in the parent country's corporate tax

\footnotetext{
${ }^{15}$ Slemrod (1990) was the first who has pointed to a positive relationship between the parent country tax rate and outbound FDI, especially under the exemption system. In this regard, Hartman (1990, p. 121) criticized that "... the sign of the home country taxation parameter is indeterminate from economic theory." According to the insights from our model, Slemrod rightfully suggested using parent country corporate tax rates as a determinant of outbound FDI.

${ }^{16}$ In the case of identical factor endowments, the impact of a parent country's tax increase on foreign affiliate activity is only positive if both countries are in an excess credit position, i.e., $\left(t_{j}-t_{i}^{w}\left(1-t_{i}\right)\right)<t_{i}<\left(t_{j}+t_{j}^{w}\left(1-t_{j}\right)\right)$, obtaining the same result as with the exemption method.

${ }^{17}$ As discussed above, the deduction method leads to zero MNE activity for a small country. For such a situation, we are not able to identify a change in MNE activity due to an increase in the tax parameters. However, to illustrate the impact of tax changes we re-parameterize the model such that MNE activity arises in the initial equilibrium (see footnote $b$ in Table 1).
} 
rate fosters its foreign affiliate activity at the expense of the NE activity there.

The impact of withholding tax rates on MNE activity: The effects of an increase in the withholding tax rate are unambiguous and straight-forward. An increase in the host country's withholding tax rate increases the tax burden of the parent country's MNEs only, irrespective of the method of double taxation relief. Consequently, MNE activity there is then reduced.

The impact of depreciation allowances on MNE activity: If the parent country provides more generous depreciation allowances (reflected in a higher level of $\delta_{i}$ ), the model predicts an increase of the parent's horizontal outbound MNE activity. The reason for this result lies in the assumption that fixed costs are deductible in the country where they are actually paid (firm-specific and domestic plant-specific fixed costs in the parent country and foreign plant-specific fixed costs abroad). Hence, domestically headquartered MNEs gain the most, as they face the highest fixed costs. However, this effect exists only under crosshauling, i.e., the coexistence of outbound and inbound horizontal MNE activity at small (zero) relative factor endowment differences. The effects of depreciation allowances are reversed if large relative factor endowment differences exist and vertical MNEs prevail. ${ }^{18}$ Since vertical MNEs do not operate a production facility at the headquarters' location, they only can deduct fixed plant set-up costs (in contrast to domestic NEs or horizontal MNEs). Accordingly, an increase in domestic depreciation allowances leads to a distortion in favor of domestic NEs and vertical outbound MNE activity is crowded out. An increase in the depreciation allowances in an unskilled labor abundant host country attracts even more affiliate production there and fosters the parent country's vertical outbound MNE activity. In the remaining factor configurations, we obtain the opposite sign to a change in depreciation allowances in the parent country.

\section{Specification of bilateral outbound FDI}

Our empirical analysis employs a panel data set of real bilateral outbound FDI stocks among the OECD economies with annual information between 1991 and 2002. To guard against the bias from omitted time-invariant variables and time-specific common shocks that affect all country-pairs in the same way, we include fixed country-pair and time effects. The specification of the empirical

\footnotetext{
${ }^{18}$ The effects of $\delta_{i}$ and $\delta_{j}$ are also reversed if depreciation allowances are not only applied to fixed costs but also to variable costs, as indicated in Footnote 6.
} 
model follows our theoretical framework and is also in line with recent empirical research emphasizing parent and host country size, their skilled labor endowments, trade and investment costs, and interaction terms thereof as the most important determinants of MNE activity (Carr, Markusen, and Maskus, 2001; Markusen and Maskus, 2002; Blonigen, Davies, and Head, 2003). Whereas most of the estimated specifications employ dependent and independent variables in levels, Mutti and Grubert (2004) find that a specification in logs is superior from an econometric point of view.

Therefore, we specify the $\log$ of FDI stocks from country $i$ to country $j$ in year $t, F D I_{i j t}$, as a log-linear function of the following explanatory variables. The sum of parent and host country GDP in period $t, \Sigma G D P_{i j t}=$ $\log G D P_{i t}+\log G D P_{j t}$, the similarity between the parent and the host market in country size, $\triangle G D P_{i j t}^{2}=\left(\log G D P_{i t}-\log G D P_{j t}\right)^{2}$, and four interaction terms to account for the impact of knowledge-capital (skilled labor endowment differences, $\left.\Delta S K_{i j t}=\log S K_{i t}-\log S K_{j t}\right)$ on FDI: $I N T 1_{i j t}=$ $\Delta S K_{i j t} \times \Delta G D P_{i j t} \times \mathbf{I}\left(\Delta S K_{i j t}>0\right)$, where $\Delta G D P_{i j t}=\left(\log G D P_{i t}-\log G D P_{j t}\right)$ and $\mathbf{I}\left(\Delta S K_{i j t}>0\right)$ is a dummy variable that is set to 1 , if $\Delta S K_{i j t}>0$, and 0 else; $I N T 2_{i j t}=\Delta S K_{i j t} \times \Sigma G D P_{i j t} \times \mathbf{I}\left(\Delta S K_{i j t}>0\right) ; I N T 3_{i j t}=-\Delta S K_{i j t} \times$ $\Sigma G D P_{i j t} \times \mathbf{I}\left(\Delta S K_{i j t}<0\right)$, where $\mathbf{I}\left(\Delta S K_{i j t}<0\right)$ is a dummy variable that is set to 1 , if $\Delta S K_{i j t}<0$, and 0 else; and $I N T 4_{i j t}=\Delta S K_{i j t} \times \log D I S T_{i j}$, where $D I S T_{i j}$ is the great circle distance between the parent's and the host's capitals, serving as a proxy for trade costs. According to the literature, horizontal FDI is expected to rise, if the two economies become larger and more similar (i.e., $\Sigma G D P_{i j t}$ rises and $\Delta G D P_{i j t}$ declines). Vertical FDI is expected to increase, if the parent country becomes smaller and/or relatively better endowed with skilled labor, especially, if the trade costs between the two countries are low. Hence, we expect a positive sign for the parameters of $\Sigma G D P_{i j t}$ and $\triangle G D P_{i j t}^{2}$, but a negative one for the parameters of $I N T 1_{i j t}, \ldots, I N T 4_{i j t}$.

In addition to the variables motivated by the original knowledge-capital model, the above variant of it supports the use of the following components of country-pair specific (bilateral) tax rates: the parent and the host country statutory corporate tax rates $\left(t_{i t}, t_{j t}\right)$, whose impact depends on the prevailing method of double taxation relief established in tax treaties (i.e., exemption, credit, and deduction) $;{ }^{19}$ the withholding tax rate applying to repatriated prof-

\footnotetext{
${ }^{19}$ Note that for about 97 percent of the observations a tax treaty is effective. Of the remaining three percent, about one percentage point (i.e., 18) of the observations are covered by the European Union's Parent-Subsidiary Directive (Directive 90/435) that applies to FDI within the European Union. For the remaining two percent (i.e., 54) observations in our database, methods of double taxation relief (exemption, credit, deduction) are applied unilaterally.
} 
its in a given host country $\left(t_{j t}^{w}\right)$; and the parent and host country-specific net present values of depreciation allowances $\left(\delta_{i t}, \delta_{j t}\right)$. To avoid a possible endogeneity bias, we use the lagged values of all tax variables. ${ }^{20}$

Regarding the parent country's statutory tax rate, we have no clear-cut hypothesis on the sign of the parameter estimate. However, the above theoretical model suggests that its impact depends on the skilled-to-unskilled labor endowment ratio in the parent country relative to the host (see Table 1). We include the interaction term $t_{i, t-1} \times \Delta S K_{i j, t-1} \times \mathbf{I}\left(\Delta S K_{i j, t-1}>0\right)$, where we expect a positive sign for the exemption as well as the credit method. Additionally, we include the present values of depreciation allowances, $\delta_{i, t-1}$ and $\delta_{j, t-1}$, and two interaction terms between the depreciation allowances and the skill differences, $\delta_{i, t-1} \times \Delta S K_{i j, t-1} \times \mathbf{I}\left(\Delta S K_{i j, t-1}>0\right)$ and $\delta_{j, t-1} \times \Delta S K_{i j, t-1} \times \mathbf{I}\left(\Delta S K_{i j, t-1}>0\right)$. Similar to the parent country statutory corporate tax rate, the inclusion of these interaction terms is necessary, since the theoretical model does not predict a clear-cut relationship between the depreciation allowances and outbound FDI. The theoretical model predicts a negative parameter for the first and a positive one for the second interaction term.

Overall, the empirical specification reads as follows

$$
\begin{aligned}
F D I_{i j t} & =\beta_{1} t_{i, t-1}+\beta_{2} t_{j, t-1}+\beta_{3} t_{j, t-1}^{w}+\beta_{4} \delta_{i, t-1}+\beta_{5} \delta_{j, t-1} \\
& +\beta_{6}\left[t_{i, t-1} \times \Delta S K_{i j, t-1} \times \mathbf{I}\left(\Delta S K_{i j, t-1}>0\right)\right] \\
& +\beta_{7}\left[\delta_{i, t-1} \times \Delta S K_{i j, t-1} \times \mathbf{I}\left(\Delta S K_{i j, t-1}>0\right)\right] \\
& +\beta_{8}\left[\delta_{j, t-1} \times \Delta S K_{i j, t-1} \times \mathbf{I}\left(\Delta S K_{i j, t-1}>0\right)\right] \\
& +\beta_{9} \Sigma G D P_{i j t}+\beta_{10} \Delta G D P_{i j t}^{2}+\beta_{11} I N T 1_{i j t}+\beta_{12} I N T 2_{i j t} \\
& +\beta_{13} I N T 3_{i j t}+\beta_{14} I N T 4_{i j t}+\mu_{i j}+\lambda_{t}+\varepsilon_{i j t}
\end{aligned}
$$

where $\mu_{i j}$ and $\lambda_{t}$ are fixed country pair and time effects, respectively. $\varepsilon$ is an identically and independently distributed stochastic error term.

\section{Empirical analysis}

Baseline results: We provide details on the data sources and descriptive statistics for all variables in the Appendix (Tables A1 to A3) and in Figure 4. The figure illustrates the change in all considered components of corporate tax-

\footnotetext{
${ }^{20}$ Given the large number of taxation-related variables (eight) it seems infeasible to employ instrumental variable methods. However, with panel data one can use lagged values of the tax variables to get rid of the endogeneity problem as long as the contemporaneous variation in foreign direct investment does not cause a change in taxation in the past.
} 
ation: parent and host country statutory corporate tax rates, their depreciation allowances, and the host economy's withholding tax rate.

The figure covers the same sample of host countries and years that is considered in the empirical analysis. We report the mean as well as the minimum and maximum values of each tax parameter and year. Obviously, there is enough time variation in every component, rendering parameter estimation by a fixed effects model feasible.

Table 2 summarizes the results for (i) the full sample (covering all countrypairs and years, independent of the implemented method of double taxation relief), (ii) the sub-sample covering the country-pairs which apply the exemption method, and (iii) the sub-sample covering country-pairs which apply the credit method. ${ }^{21}$

To facilitate the comparison of the point estimates with the theoretical hypotheses, we indicate in Table 2 whether our findings are in line with the predictions (labelled ' $Y$ ') or not (' $N$ '). If the expected effects are ambiguous according to Table 1, i.e., for the entries '+/-' (e.g., the credit method), this is indicated by a '?' in the table. All estimated standard errors and test statistics are corrected for heteroskedasticity and autocorrelation, following Newey and West (1987). In general, the model fit is quite well. Inspired by Razin, Rubinstein, and Sadka (2005) we check for a potential bias due to sample selection arising from missing FDI data. We follow Wooldridge $(1995,2002)$ in applying testing procedures that are suited for panel data. However, in our sample of OECD country-pairs, there is no indication for endogenous selection into the sample, given the adopted specification. This can be seen from the insignificant parameters of the inverse Mills' ratio reported in Table 2. With regard to the usual knowledge-capital variables, we find across the board that the impact of overall and relative country size $\left(\Sigma G D P_{i j t}\right.$ and $\left.\Delta G D P_{i j t}^{2}\right)$ is in line with theory, whereas the skill-endowment interaction term parameters $\left(I N T 1_{i j t}, \ldots, I N T 4_{i j t}\right)$ are insignificant in almost all specifications. ${ }^{22}$ In

\footnotetext{
${ }^{21}$ In our sample, the exemption (credit) method applies for around 59 percent (34 percent) of the observations (either through unilateral tax law or through bilateral tax treaties). The remaining observations use the deduction method (around 7 percent). Since the latter group contains only 149 observations, it is not possible to estimate the tax effects precisely for the deduction sub-sample.

${ }^{22}$ In this regard, our findings do not match with the empirical results in Carr, Markusen, and Maskus (2001) and Markusen and Maskus (2002). However, there are four reasons for this. First, we use stocks of outbound FDI rather than foreign affiliate sales as our dependent variable (however, Blonigen, Davies, and Head, 2003, indicate that the results tend to be very similar for FDI and foreign affiliate sales). Second, we apply a log-linear specification (as suggested by Mutti and Grubert, 2004) rather than one in levels. Third, our sample covers a panel of OECD parent and host countries that are relatively similarly endowed, which differs
} 

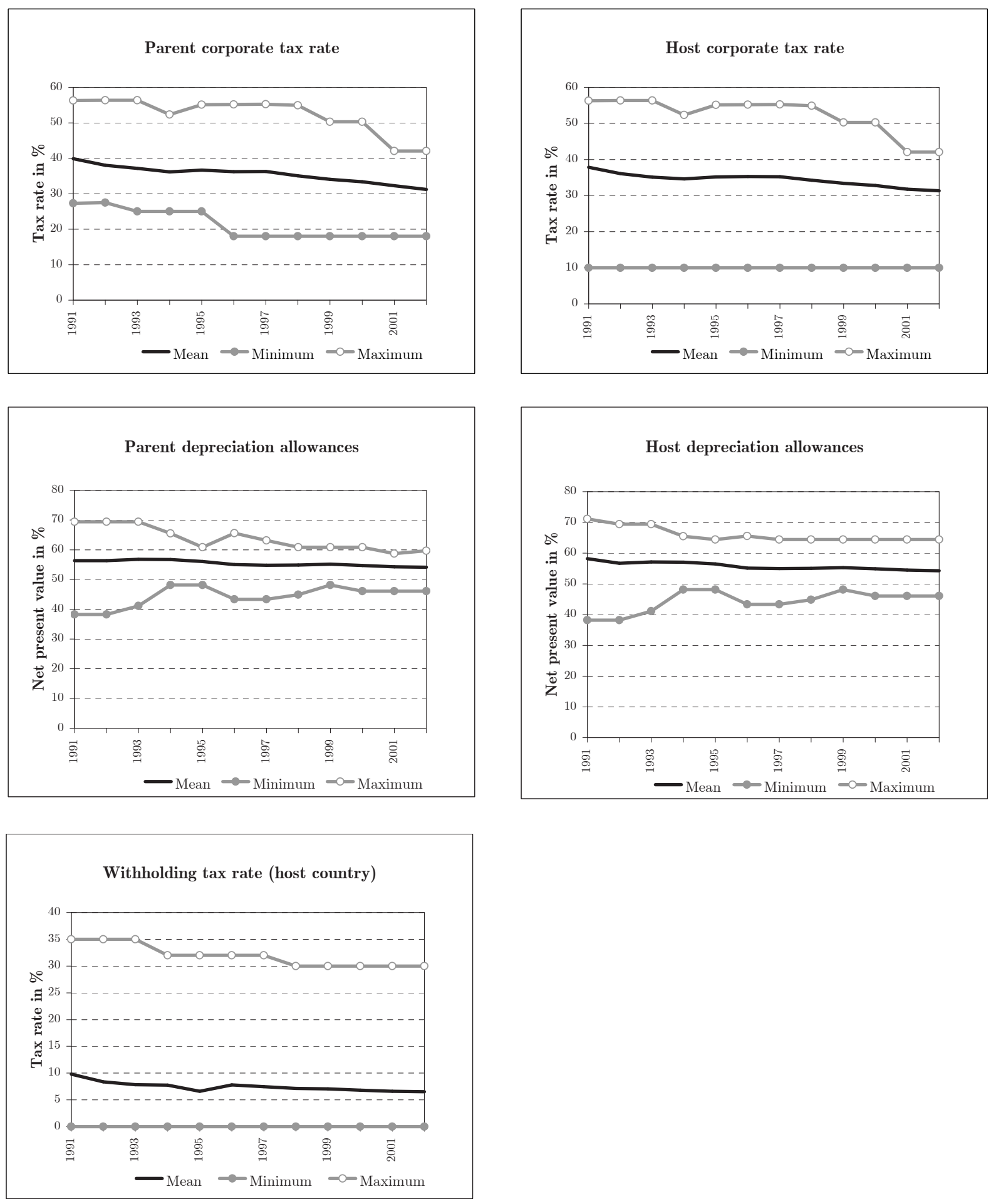

Figure 4: Tax components in parent and host countries, 1991-2002 


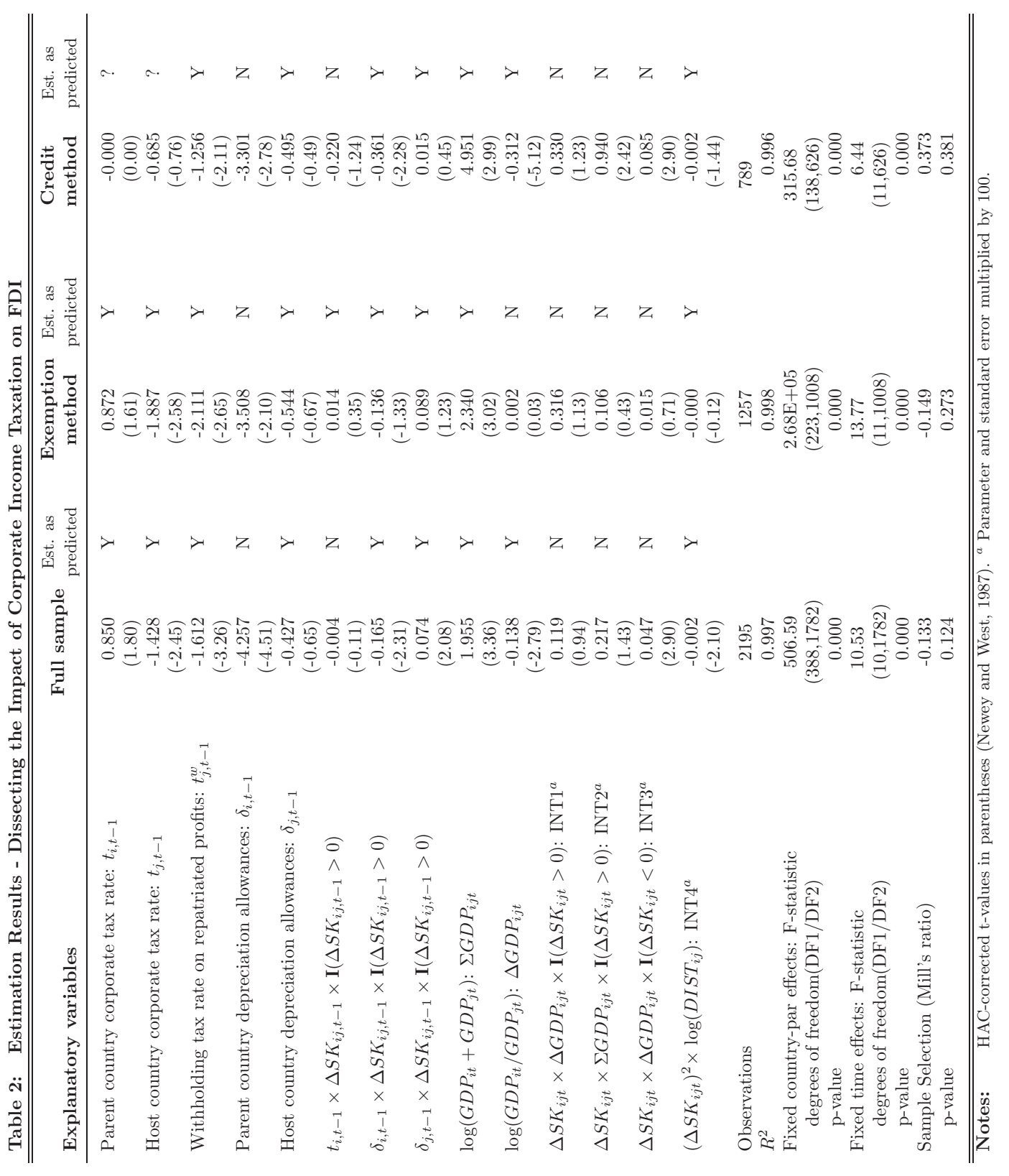


the subsequent discussion of Table 2, we summarize our findings regarding the impact of the tax variables on bilateral outbound FDI in the OECD.

In general, we would expect that the parent country tax rate exerts a positive impact on the country's outbound FDI. ${ }^{23}$ This is in line with the positive point estimate in the pooled sample and in the exemption sub-sample. For instance, the point estimate in the full sample indicates that a one percentage point increase in the parent country statutory tax rate $\left(t_{i, t-1}\right)$ is associated with an increase in outbound FDI by about 0.85 percent. For the credit method sub-sample, the impact of the parent country corporate tax rate is theoretically ambiguous, which is in line with our findings. The interactive term $t_{i, t-1} \times \Delta S K_{i j, t-1} \times \mathbf{I}\left(\Delta S K_{i j, t-1}>0\right)$ enters as expected in the sub-sample covering the exemption countries, but not so in the full sample and in the credit sub-sample. Regarding the host country corporate tax rate, we expect a negative impact on a country's outbound FDI. ${ }^{24}$ This is confirmed by the empirical finding of a significantly negative estimate of the corresponding parameter. Similarly, Table 1 clearly suggests a negative relationship between the host country withholding tax rate and outbound FDI, which is confirmed by the significantly negative parameter estimates in all samples. Finally, the parent country depreciation allowances $\left(\delta_{i, t-1}\right)$ exert a significantly negative impact on foreign outbound FDI, which is not supported by the simulations in Table 1. A negative but insignificant effect is estimated for its host country counterpart $\left(\delta_{j, t-1}\right)$, as expected. Further, the point estimate of $\delta_{i, t-1} \times \Delta S K_{i j, t-1} \times \mathbf{I}\left(\Delta S K_{i j, t-1}>0\right)$ is negative, and the one of $\delta_{j, t-1} \times \Delta S K_{i j, t-1} \times \mathbf{I}\left(\Delta S K_{i j, t-1}>0\right)$ is positive, being in line with the theoretical hypotheses. Across the board, the support for the tax-related hypotheses is remarkable, considering the large number of parameters to be estimated.

Sensitivity analysis and discussion: We check the sensitivity of our findings in various ways. Table 3 provides a summary, pointing to their robustness in qualitative terms. For the sake of brevity, we refer to the full sample in Table

from that one in Carr, Markusen, and Maskus (2001) and Markusen and Maskus (2002), who use U.S. foreign affiliate sales across a larger set of host countries over time. Finally, we employ country-pair and time fixed effects. In particular, this wipes out all time-invariant level information so that the parameters of the relatively time-invariant endowment variables can hardly be estimated significantly.

${ }^{23}$ The predicted impact across all methods (i.e., the pooled sample) is ambiguous (see Table 1). However, the number of cases in our sample, where deduction is applied or the excess credit position is evident is rather small. Accordingly, we expect the positive impact to dominate in the pooled sample.

${ }^{24}$ Again, the prediction is ambiguous, but we expect the negative impact to dominate for the same reasons as in the previous footnote. 
2 and only report the taxation parameters of interest.

In the first sensitivity check, we replace tertiary school enrollment by alternative skill measures in the construction of $I N T 1_{i j t}, \ldots, I N T 4_{i j t}$ and the interaction terms involving $\Delta S K_{i j, t-1}$ : gross secondary school enrollment in Model $A$; the sum of professional, technical, kindred and administrative workers to total employment in Model B (as in Carr, Markusen, and Maskus 2001; and Markusen and Maskus, 2002); and physical capital stocks per worker in Model $C$. As can be seen, most of the point estimates, especially the ones of statutory tax rates and depreciation allowances, exhibit the same sign as in Table 2. Only in the case of host country depreciation allowances $\left(\delta_{j, t-1}\right)$ we obtain positive but insignificant parameter estimates in Models $A$ and $C$ which should be negative according to the predictions of the theoretical model. Similarly, the sign of $\delta_{i, t-1} \times \Delta S K_{i j, t-1} \times \mathbf{I}\left(\Delta S K_{i j, t-1}>0\right)$ is now positive in Models $A$ and $C$ (it was and should be negative), and the coefficient of $\delta_{j, t-1} \times \Delta S K_{i j, t-1} \times \mathbf{I}\left(\Delta S K_{i j, t-1}>0\right)$ becomes positive in Models $B$ and $C$ (it was negative in Table 2 , as expected). $t_{i, t-1} \times \Delta S K_{i j, t-1} \times \mathbf{I}\left(\Delta S K_{i j, t-1}>0\right)$ is now positive in Models $B$ and $C$, as it should be (it was negative before). Generally, we would prefer the original model in Table 2 and Model $A$ in Table 3 over Models $B$ and $C$, since the sample size is substantially reduced for the latter ones (to 1011 and 1410 observations, respectively). Further, as can be seen from Table A3 in the Appendix, the correlation between the interaction effects is much lower for tertiary school enrollment than for secondary school enrollment. Therefore, we consider the original model as preferable over Model A.

The second sensitivity check (Model $D$ ) replaces the knowledge-capital model variables that are not related to corporate taxation by standard gravity model variables (i.e., parent and host country GDP and GDP per capita). For instance, such a specification is employed by Mutti and Grubert (2004), Bénassy-Quéré, Fontagné, and Lahrèche-Révil (2005), and also by Blonigen and Davies (2004) in a paper on the tax treaty effects on FDI. In Model $D$, the parameter signs are very similar to their counterparts in the original model, except for the interaction effects $t_{i, t-1} \times \Delta S K_{i j, t-1} \times \mathbf{I}\left(\Delta S K_{i j, t-1}>0\right)$, $\delta_{i, t-1} \times \Delta S K_{i j, t-1} \times \mathbf{I}\left(\Delta S K_{i j, t-1}>0\right)$ and $\delta_{j, t-1} \times \Delta S K_{i j, t-1} \times \mathbf{I}\left(\Delta S K_{i j, t-1}>0\right)$, which have changed their sign. $t_{i, t-1} \times \Delta S K_{i j, t-1} \times \mathbf{I}\left(\Delta S K_{i j, t-1}>0\right)$ is now significantly positive, as expected. However, it must be said that a test on the joint significance of the skilled labor endowment variables $I N T 1_{i j t}, \ldots, I N T 4_{i j t}$ indicates that the gravity specification is less suitable than the knowledge-capital 


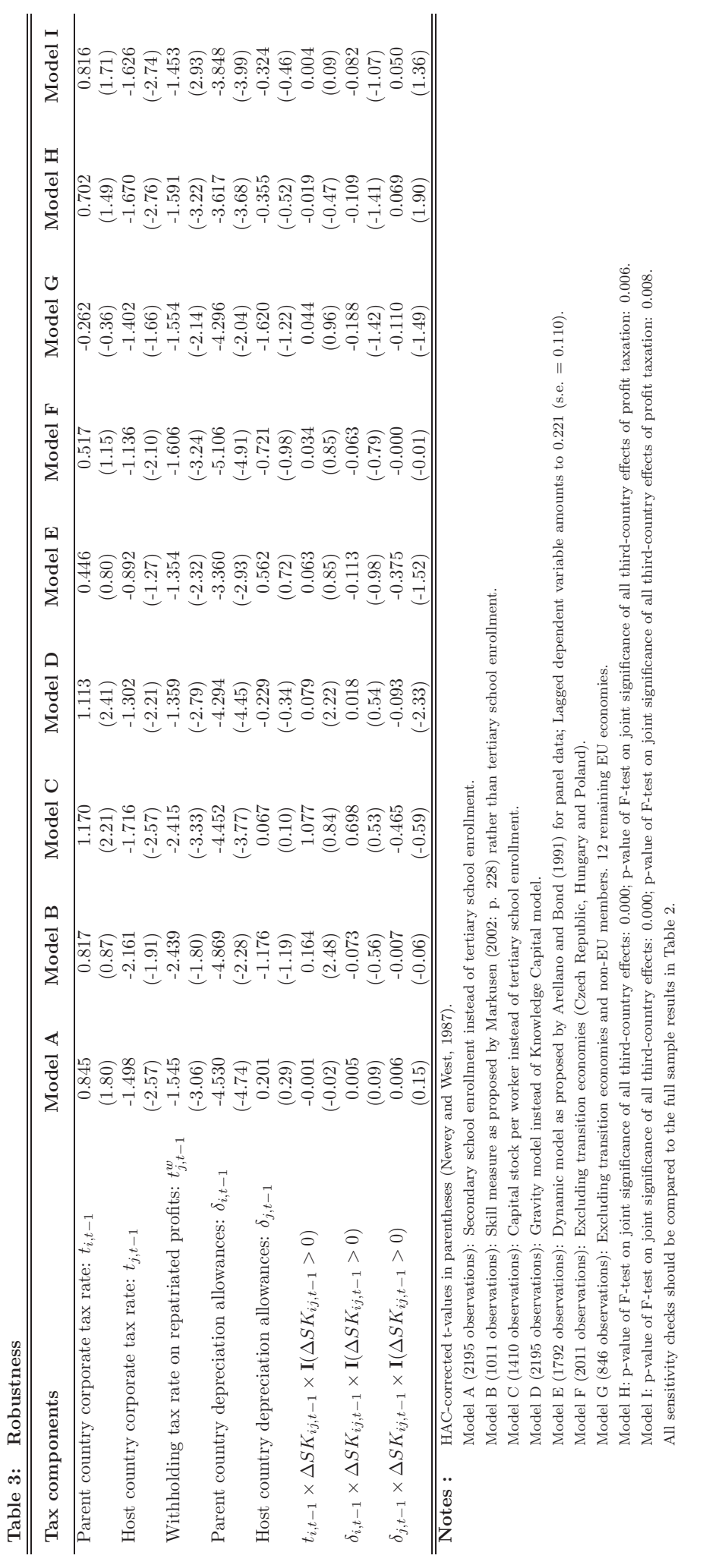


model for bilateral FDI in our sample of country-pairs and years.

Next, we estimate a dynamic model including lagged outward FDI stocks on the right-hand-side of the regression (Model E; see Devereux and Freeman, 1995, for such a specification). To avoid an endogeneity bias inherent in dynamic panel data models with fixed effects (see Baltagi, 2005, p. 135), we use a GMM estimator based on first differences as proposed by Arellano and Bond (1991). However, the estimated parameter for the lagged dependent variable is rather low at 0.22 and not significant at 10 percent (see the notes of Table 3 ). The remaining coefficients are very close to the original ones (with the exceptions of $t_{i, t-1} \times \Delta S K_{i j, t-1} \times \mathbf{I}\left(\Delta S K_{i j, t-1}>0\right)$ and $\delta_{j, t-1} \times \Delta S K_{i j, t-1} \times \mathbf{I}\left(\Delta S K_{i j, t-1}>0\right)$, where the signs change).

Furthermore, we exclude the transition economies (Model $F$ ) and, alternatively, the transition countries as well as the non-EU members from the sample (Model $G$ ). Especially the transition economies have reduced their statutory corporate tax rates significantly within the sample period and faced a strong increase in inward FDI at the same time, which might exert a crucial impact on the estimation results. However, with the exception of the interaction terms $t_{i, t-1} \times \Delta S K_{i j, t-1} \times \mathbf{I}\left(\Delta S K_{i j, t-1}>0\right)$ and $\delta_{j, t-1} \times \Delta S K_{i j, t-1} \times \mathbf{I}\left(\Delta S K_{i j, t-1}>0\right)$ we obtain the same signs for the coefficients of interest in Model $F$ as in the original model. In Model $G$, several of the originally significant parameter estimates are now insignificant, especially the one of the host country statutory tax rate. This comes at no surprise, since the sample size is dramatically reduced to only 846 observations in this experiment.

In the last two exercises, we control for weighted third-country explanatory variables to make sure that the parameters of the bilateral variables are not affected qualitatively by the exclusion of third-country effects in the regressions. An inclusion of third-country explanatory variables can be justified from the perspective of recent theoretical work on complex multinational firms (see Yeaple, 2003; Ekholm, Forslid, and Markusen, 2005; and Grossman, Helpman, and Szeidl, 2006). In particular, Model $H$ includes simple third-country averages of all explanatory variables. ${ }^{25}$ Model $I$ includes inverse-distance-weighted

\footnotetext{
${ }^{25}$ For instance, the third-market parent country corporate tax rate is the simple average of the lagged corporate tax rate of all other parent countries in a particular year, and similarly for all other variables that vary across parent countries and years only. In contrast, the thirdmarket host country corporate tax rate is the simple average of the lagged corporate tax rate of all other host countries in a particular year, and similarly for all other variables that vary across host countries and years only. Finally, all variables that vary across country-pairs are simple averages across the parent and host country dimensions in each year. Not only the tax parameters but also all other explanatory variables enter in their bilateral and their third-market form, simultaneously.
} 
averages of the third-market variables instead. ${ }^{26}$ The third-market variables are jointly significant according to the F-tests in Table 3. Yet, the exclusion of third-market variables from our original specifications does not exert a qualitative impact on the bilateral determinants of interest. This is not as surprising, since third-market averages of the explanatory variables do not vary much in the time dimension. Controlling for all time-invariant variables in our fixed country-pair effects framework reduces their correlation with the bilateral effects substantially, so that a possible bias in the parameter estimates is avoided.

How do the results relate to those in previous research? Similar to the above mentioned evidence regarding U.S. outbound FDI (see, e.g., Grubert and Mutti, 1991, 2000; Hines and Rice, 1994; Mutti and Grubert, 2004; Desai, Foley, and Hines, 2005), parent (host) country tax rates exert a positive (negative) impact on outward FDI in our large panel of countries. Our point estimates of 0.850 (for parent's corporate tax rate) and -1.428 (for host's corporate tax rate) for the full sample in Table 2 translate into an elasticity of 0.3 and -0.5 , respectively. These values are at the lower bound of the range of results in previous studies (see de Mooij and Ederveen, 2003). However, one should be careful with such a direct comparison, since we control for withholding tax rates and depreciation allowances beyond the statutory corporate tax rates. The present results clearly indicate that it is decisive to consider these variables in addition to the statutory tax rates when analyzing the impact of company taxation on FDI.

\section{Conclusions}

This paper analyzes the role of corporate taxation for outbound FDI. In doing so, the paper pays particular attention to the fact that FDI flows among the developed economies are not subject to country-specific but rather to countrypair-specific taxation. This follows from the prevalence of tax treaties (or the Parent-Subsidiary-Directive within the EU) among these countries, where deviations from unilateral taxation principles are the rule rather than the exception. One could think of bilateral effective tax rates as nonlinear aggregates of their components: parent and host country statutory corporate tax rates, where the

\footnotetext{
${ }^{26}$ Note that market interdependencies are assumed to be inversely related to distance, since complex multinationals engage in trade (see Blonigen, Davies, Waddell, and Naughton, 2004, for an application). There, we apply the weights $e^{-D I S T_{k l}}$ to compute the respective averages. $D I S T_{k l}$ denotes the great circle distance between the economic centers of countries $k$ and $l$. In this way, our specification simultaneously accounts for interdependencies among parent countries and among host economies (see Blonigen, Davies, Waddell, and Naughton, 2004, 2005 , for a separate treatment of these interdependencies).
} 
levels of the former depend on the applied assignment of taxing rights (i.e., credit, exemption or deduction method), bilateral withholding tax rates, and depreciation allowances. These components exert a non-monotonic impact on FDI. Accordingly, economic theory motivates an analysis of the role of corporate taxation on FDI at the level of separate tax parameters rather than effective tax rates.

The hypotheses can be derived from a theoretical approach that distinguishes between the respective parameters. For this, we employ a knowledgecapital general equilibrium model of national and multinational firms as the underlying framework. An empirical analysis relying on the components of corporate taxation has not yet been pursued. A crucial prerequisite for such an analysis is the availability of a data base that disentangles these components. We construct such a data base for all country-pairs covering 26 OECD economies and the period 1991 to 2002. Our empirical findings for the role of corporate taxation on FDI stocks within this sample provide strong support for the hypothesis derived in a knowledge-capital general equilibrium model of national and multinational firms. By and large, an increase in parent (host) country statutory tax rates tends to foster (reduce) outbound FDI stocks. Host country withholding tax rates exert an unambiguously negative impact on outbound FDI. Parent and host country depreciation allowances have a non-monotonic impact on outbound FDI, as expected from our theoretical model. The signs of several of the parameters inherently depend on the relative factor endowment configurations as predicted by the knowledge-capital model of multinational firms.

\section{Acknowledgements}

We are grateful to Michael Devereux, Eckhard Janeba, Assaf Razin, Nadine Riedel, Efraim Sadka, Hans-Werner Sinn and participants at the annual meetings of the Austrian Economic Society, the Canadian Economic Association, the Western Economic Association, the CESifo "Global Economy" area conference, the ZEW Summer Workshop on "EU Countries in Fiscal Competition" in Mannheim, and seminars at the Universities of Innsbruck, Paderborn and at the ifo Institute for helpful comments and suggestions. Financial support from the Austrian Fond zur Förderung der wissenschaflichen Forschung (FWF, grant no. P 17028-G05) is gratefully acknowledged. 


\section{References}

Altshuler, R., H. Grubert, and T.S. Newlon, 2001. Has US investment abroad become more sensitive to tax rates?, in J.R. Hines, Jr. (ed.), International Taxation and Multinational Activity, Chicago: University of Chicago Press.

Alworth, J.S., 1988. The finance, investment and taxation decisions of multinationals, Oxford: Blackwell.

Arellano, M. and S. Bond, 1991. Some tests of specification for panel data: Monte Carlo evidence and an application to unemployment equations, The Review of Economic Studies 58, 277-294.

Baier, S., G.P. Dwyer, and R. Tamura, 2002. How important are capital and total factor productivity for economic growth?, unpublished manuscript, Clemson University.

Baltagi, B.H., 2005. The econometrics of panel data, 3rd ed., Chichester: John Wiley \& Sons.

Bartik, T.J., 1985. Business location decisions in the United States: estimates of the effects of unionization, taxes and other characteristics of States, Journal of Business and Economic Statistics 3, 14-22.

Bénassy-Quéré, A., L. Fontagné, and A. Lahrèche-Révil, 2005. How does FDI react to corporate taxation?, International Tax and Public Finance 12, 583-603.

Blonigen, B.A. and R.B. Davies, 2004. The effects of bilateral tax treaties on U.S. FDI activity, International Tax and Public Finance 11, 601-622.

Blonigen, B.A., R.B. Davies, and K. Head, 2003. Estimating the knowledgecapital model of the multinational enterprise: Comment, American Economic Review 93, 980-994.

Blonigen, B.A., R.B. Davies, G.R. Waddell, and H.T. Naughton, 2004. FDI in space: Spatial autoregressive relationships in foreign direct investment, NBER Working Paper No. 10939, Cambridge MA: National Bureau of Economic Research.

Blonigen, B.A., R.B. Davies, G.R, Waddell, and H.T. Naughton, 2005.

Spacey parents: spatial autoregressive patterns in inbound FDI, NBER Working Paper No. 11466, Cambridge MA: National Bureau of Economic Research.

Bond, E.W. and L. Samuleson, 1989. Strategic behavoir and the rules for international taxation of capital, The Economic Journal 99, 1099-1111.

Braconier, H., P.-J. Norbäck, and D. Urban, 2005. Reconciling the evidence of the knowledge capital model, Review of International Economics, forthcoming. 
Carr, D., J.R. Markusen, and K.E. Maskus, 2001. Estimating the knowledgecapital model of the multinational enterprise, American Economic Review 91, 693-708.

Carstensen, K. and F. Toubal, 2004. Foreign direct investment in Central and Eastern European countries: a dynamic panel analysis, Journal of Comparative Economics 32, 3-22.

Clark, S.W., 2000. Tax incentives for foreign direct investment: Empirical evidence on effects and alternative policy options, Canadian Tax Journal 48, 1139-1180.

Coughlin, C.C., J.V. Terza, and V. Arromdee, 1991. State characteristics and the location of foreign direct investment within the United States, Review of Economics and Statistics 68, 675-683.

Cummins, J.G. and R.G. Hubbard, 1995. The tax sensitivity of foreign direct investment: Empirical evidence from firm level panel data, in M. Feldstein (ed.), The Effects of Taxation on Multinational Corporations, Chicago: Chicago University Press.

Davies, R.B., 2003. The OECD model tax treaty: Tax competition and twoway capital flows, International Economic Review 44, 725-753.

Davies, R.B., 2004. Tax treaties and foreign direct investment: Potential versus performance, International Tax and Public Finance 11, 775-802.

de Mooij, R.A. and S. Ederveen, 2003. Taxation and foreign direct investment: a synthesis of empirical research, International Tax and Public Finance 10, 673-693.

Desai, M.A., F.C. Foley, and J.R. Hines, 2005. The demand for tax haven operations, Journal of Public Economics, forthcoming.

Devereux, M.P., 2006. The impact of taxation on the location of capital, firms and profit: A survey of empirical evidence, unpublished manuscript, University of Warwick.

Devereux, M.P. and H. Freeman, 1995. The impact of tax on foreign direct investment: Emprical evidence and the implications for tax integration schemes, International Tax and Public Finance 2, 85-106.

Devereux, M.P. and R. Griffith, 1998. Taxes and the location of production: evidence from a panel of US multinationals, Journal of Public Economics $68,335-367$.

Devereux, M.P. and R. Griffith, 1999. The taxation of discrete investment choices, IFS Working Paper No. W98/16, London: Institute for Fiscal Studies.

Devereux, M.P. and R. Griffith, 2003. Evaluating tax policy for location decisions, International Tax and Public Finance 10, 107-126. 
Devereux, M.P., R. Griffith, and A. Klemm, 2002. Corporate income tax reforms and international tax competition, Economic Policy 35, 451-495.

Devereux, M.P. and G.R. Hubbard, 2003. Taxing multinationals, International Tax and Public Finance 10, 469-487.

Devereux, M.P. and B. Lockwood, 2006. Taxes and the size of the foreignowned capital stock: Which tax rates matter?, unpublished manuscript, University of Warwick.

Dixit, A.K. and J.E. Stiglitz, 1977. Monopolistic competition and optimum product diversity, American Economic Review 67, 297-308.

Ekholm, K., R. Forslid, and J.R Markusen, 2005. Export-platform foreign direct investment, NBER Working Paper No. 9517, Cambridge MA: National Bureau of Economic Research.

Gresik, T.A., 2001. The taxing task of taxing multinationals, Journal of Economic Literature 39, 800-838.

Grossman, G.M., E. Helpman, and A. Szeidl, 2006. Optimal integration strategies for the multinational firm, Journal of International Economics, forthcoming.

Grubert, H. and J. Mutti, 1991. Taxes, tariffs and transfer pricing in multinational corporate decision making, Review of Economics and Statistics 73, $285-293$.

Grubert, H. and J. Mutti, 2000. Do taxes influence where US multinational corporations invest?, National Tax Journal 53, 825-839.

Grubert, H. and J. Slemrod, 1998. The effect of taxes on investment and income shifting to Puerto Rico, Review of Economics and Statistics 80, $365-373$.

Hartman, D.G., 1984. Tax policy and foreign direct investment in the United States, National Tax Journal 37, 475-488.

Hartman, D.G., 1985. Tax policy and foreign direct investment, Journal of Public Economics 26, 107-121.

Hartman, D.G., 1990. Comment on Slemrod "Tax effects on foreign direct investment in the US: evidence from a cross-country comparison", in A. Razin and J. Slemrod (eds.), Taxation in the Global Economy, Chicago: University of Chicago Press.

Head, K.C., J.C. Ries, and D.L. Swenson, 1999. Attracting foreign manufacturing: Investment promotion and agglomeration, Regional Science and Urban Economics 29, 197-218.

Hines, J.R., 1996. Altered states: taxes and the location of foreign direct investment in America, American Economic Review 86, 1076-1094. 
Hines, J.R., 1997. Tax policy and the activities of multinational corporations, in A.J. Auerbach (ed.), Fiscal policy: lessons from economic research, Cambridge MA: MIT Press.

Hines, J.R., 1999. Lessons from behavioral responses to international taxation, National Tax Journal 52, 305-323.

Hines, J.R. and E.M. Rice, 1994. Fiscal Paradise: Foreign tax havens and American business, Quarterly Journal of Economics 109, 149-182.

Janeba, E., 1995. Corporate income tax competition, double taxation treaties, and foreign direct investment, Journal of Public Economics 56, 311-326.

Kellenberg, D.K., 2003. The provision of public inputs and foreign direct investment, Center for Economic Analysis Discussion Paper No. 03-11, Department of Economics, University of Colorado at Boulder

King, M.A. and D. Fullerton, 1984. The taxation of income from capital, Chicago: University of Chicago Press.

Markusen, J.R., 1997. Trade versus investment liberalization, NBER Working Paper No. 6231, Cambridge MA: National Bureau of Economic Research.

Markusen, J.R., 2002. Multinational firms and the theory of international trade, Cambridge MA: The MIT Press.

Markusen, J.R. and K.E. Maskus, 2002. Discriminating among alternative theories of the multinational enterprise, Review of International Economics 10, 694-707.

Markusen, J.R. and A.J. Venables, 1998. Multinational firms and the new trade theory, Journal of International Economics 46, 183-204.

Markusen, J.R. and A.J. Venables, 2000. The theory of endowment, intraindustry, and multinational trade, Journal of International Economics 52, 209-234.

Mutti, J. and H. Grubert, 2004. Empirical asymmetries in foreign direct investment and taxation, Journal of International Economics 62, 337-358.

Newey, W.K. and K.D. West, 1987. A simple, positive semi-definite, heteroskedasticity and autocorrelation consistent covariance matrix, Econometrica 55, 703-708.

OECD, 2001. Corporate tax incentives for foreign direct investment, OECD Tax Policy Studies No. 4, Paris: Organisation for Economic Co-operation and Development.

Razin, A., Y. Rubinstein, and E. Sadka, 2005. Corporate taxation and bilateral FDI with threshold barriers, NBER Working Paper No. 11196, Cambridge MA: National Bureau of Economic Research. 
Scholes, M.S. and M.A. Wolfson, 1990. The effects of changes in tax laws on corporate reorganization activity, Journal of Business 63, S141-S164.

Shah, A. and J. Slemrod, 1991. Do taxes matter for foreign direct investment?, World Bank Economic Review 5, 473-491.

Sinn, H.-W., 1993. Taxation and the birth of foreign subsidiaries, in H. Heber and N. van Long (Eds.), Trade, Welfare, and Economic Policies, Essays in Honor of Murray C. Kemp, University of Michigan Press: Ann Arbor.

Slemrod, J., 1990. Tax effects on foreign direct investment in the US: evidence from a cross-country comparison, in A. Razin and J. Slemrod (eds.), Taxation in the Global Economy, Chicago: University of Chicago Press.

Swenson, D.L., 1994. The impact of US tax reform on foreign direct investment in the United States, Journal of Public Economics 54, 243-266.

Swenson, D.L., 2001. Transaction type and the effect of taxes on the distribution of foreign direct investment in the United States, in J.R. Hines (ed.), International Taxation and Multinational Activity, Chicago: University of Chicago Press.

Yeaple, S.R., 2003. The complex integration strategies of multinationals and cross country dependencies in the structure of foreign direct investment, Journal of International Economics 60, 293-314.

Wooldridge, J.M., 1995. Selection corrections for panel data models under conditional mean independence assumptions, Journal of Econometrics 68, 115132 .

Wooldridge, J.M., 2002. Econometric Analysis of Cross Section and Panel Data, Cambridge, MA: MIT Press.

\section{Appendix: Data and descriptive statistics}

1. Data on foreign direct investment: We use bilateral outbound FDI stock data into Europe as published by UNCTAD (FDI Country profiles), covering the period 1991-2002.

Parent country coverage: The sample contains a total of 22 OECD parent economies: Australia, Austria, Canada, Czech Republic, Denmark, Finland, France, Germany, Hungary, Iceland, Italy, Japan, Luxembourg, Netherlands, Norway, New Zealand, Poland, Portugal, Sweden, Switzerland, United Kingdom, United States. 
Host country coverage: There are 26 host countries in the sample: Australia, Austria, Belgium, Canada, Czech Republic, Denmark, Finland, France, Germany, Greece, Hungary, Ireland, Italy, Japan, Korea, Luxembourg, Netherlands, Norway, New Zealand, Poland, Portugal, Spain, Sweden, Switzerland, United Kingdom, United States.

2. Data on country size and factor endowments: Real GDP figures at constant U.S. dollars (base year is 2000) are collected from the World Bank's World Development Indicators. Gross tertiary (and, alternatively, gross secondary) school enrollment figures from the same source serve as our measure of a country's skilled labor endowment. Capital stocks are available from Baier, Dwyer and Tamura (2002). The sum of professional, technical, kindred and administrative workers is taken from the Yearbook of Labor Statistics published by the International Labor Organization (ILO).

3. Tax rates, depreciation allowances, tax treaties: Information on tax codes and bilateral tax treaties are primarily taken from the following online databases of the International Bureau of Fiscal Documentation (IBFD):

- Central/Eastern Europe - Taxation \& Investment

- Corporate Taxation in Europe

- Tax News Service

- Tax Treaties Database

Additionally, we exploit information of tax law from the following publications:

- Baker\&McKenzie, 1999. Survey of the effective tax burden in the European Union, Amsterdam.

- Commission of the European Communities, 1992. Report of the committee of independent experts on company taxation, Brussels and Luxembourg.

- Commission of the European Communities, 2001. Towards an internal market without tax obstacles. A strategy for providing companies with a consolidated corporate tax base for their EU-wide activities, COM (2001) 582 final, Brussels.

- Ernst\&Young, 2003. Company taxation in the new EU Member states survey of the tax regimes and effective tax burdens for multinational investors, Frankfurt am Main.

- OECD, 1991. Taxing Profits in a Global Economy: Domestic and International Issues, Paris: Organisation for Economic Co-operation and Development.

- PriceWaterhouseCoopers, 1999. Spectre: Study of potential of effective corporate tax rates in Europe, Report commissioned by the Ministry of Finance in the Netherlands, Amsterdam.

- Yoo, K.-Y., 2003. Corporate taxation of foreign direct investment income 19912001, OECD Economics Department Working Paper No. 365, Paris: Organisation for Economic Co-operation and Development.

The computation of the net present value of depreciation allowances is derived in King and Fullerton (1984). The corresponding information on the number of years for which depreciations can be claimed ('depreciation rate'), the depreciation system (i.e., straight line or declining balance schedule) and on (general) investment incentives (e.g., extra first-year allowances in Australia, Poland or Spain) are taken from the above mentioned sources. In cases where a firm has several opportunities to choose from, we use the most generous one.

4. Descriptive statistics: Table A1, Table A2, Table A3 


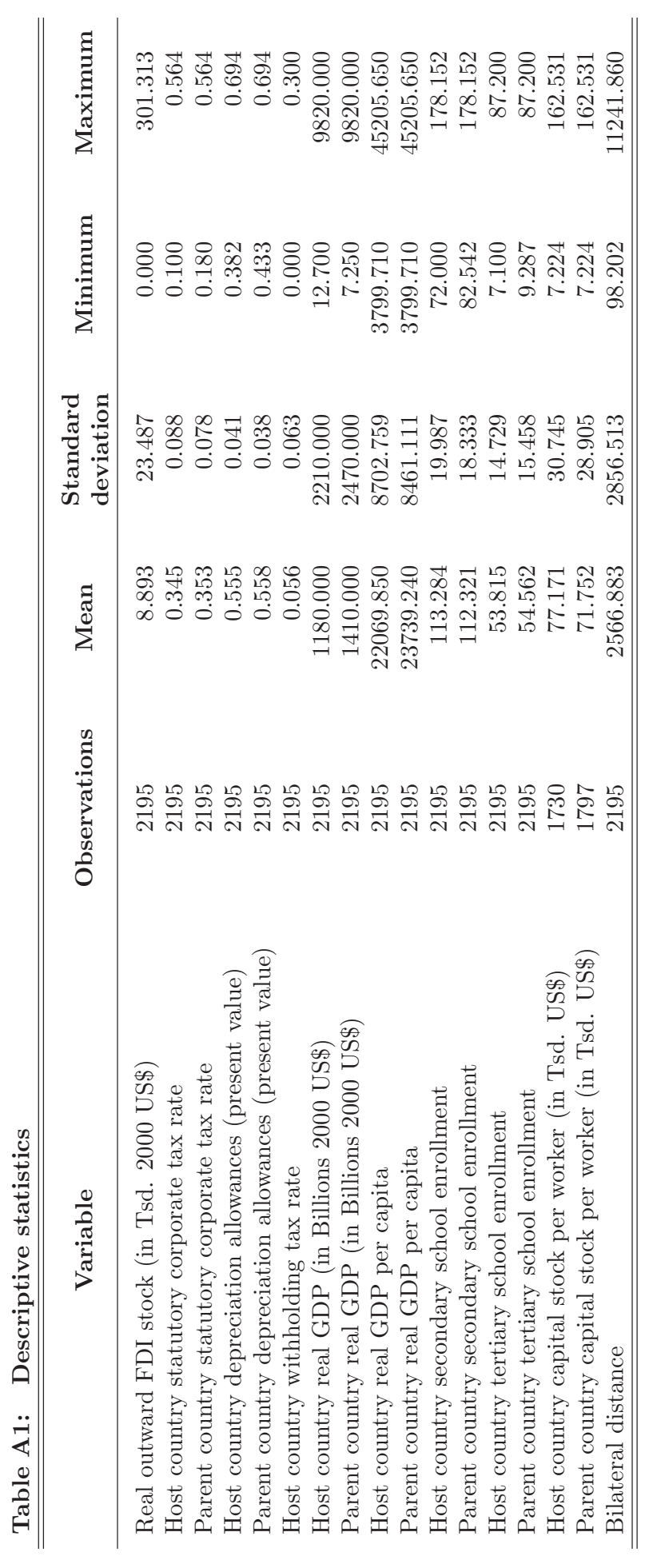




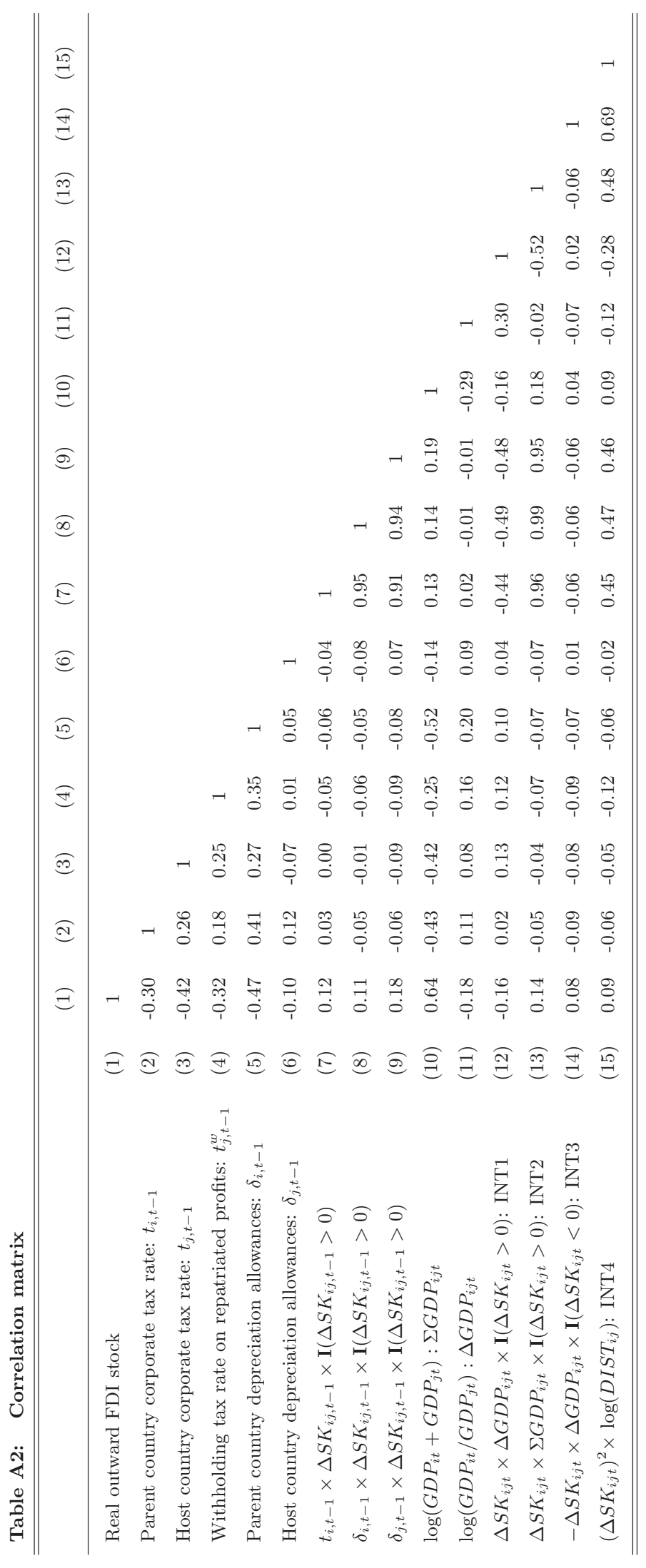




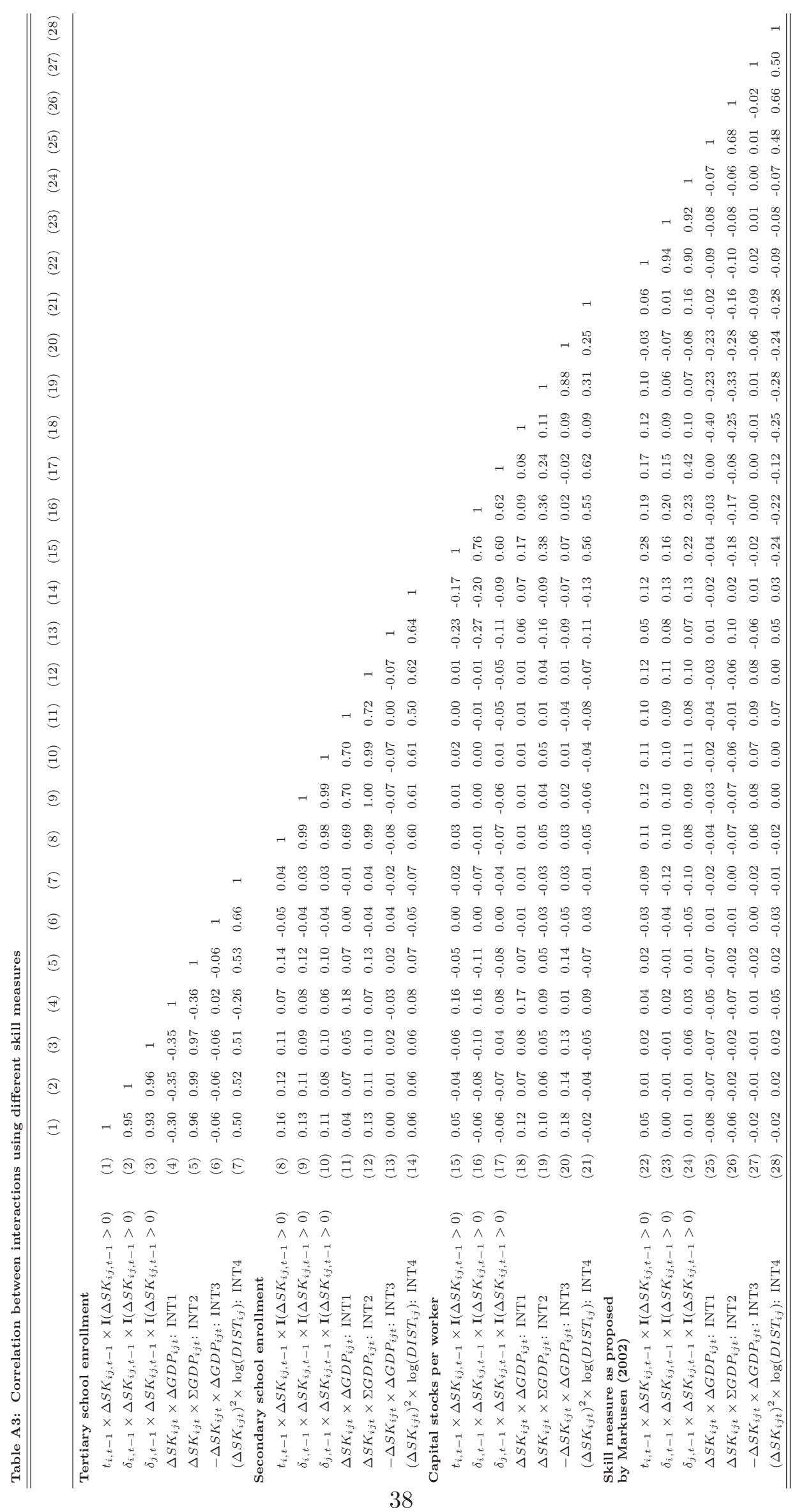




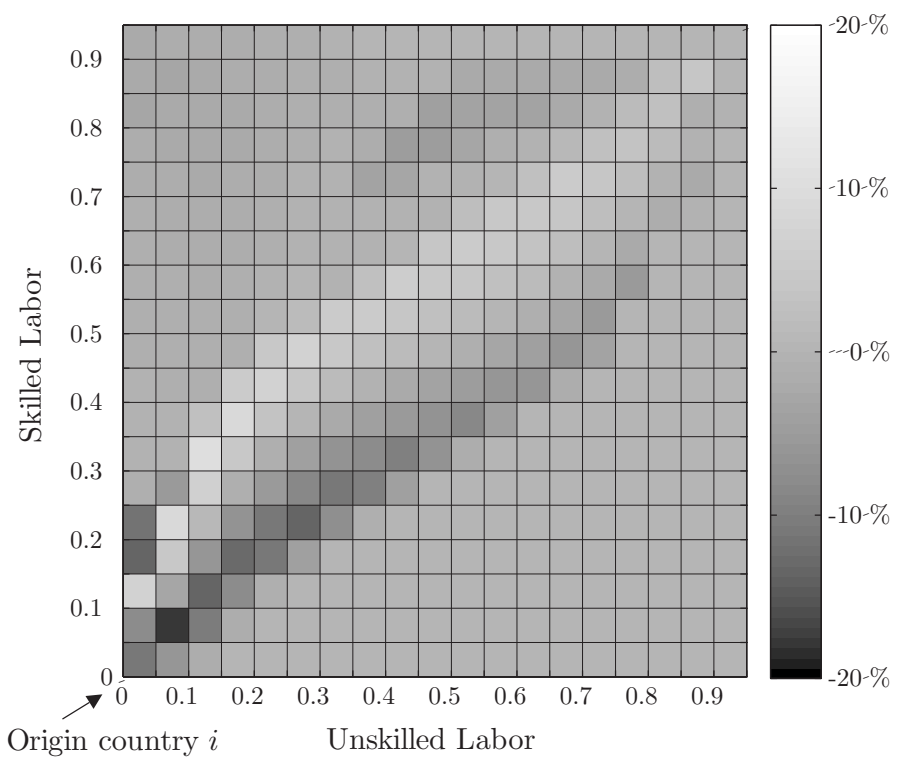

Figure 5: Difference in affiliate production with and without corporate taxation: Credit and exemption method (difference between Figures 1 and 2)

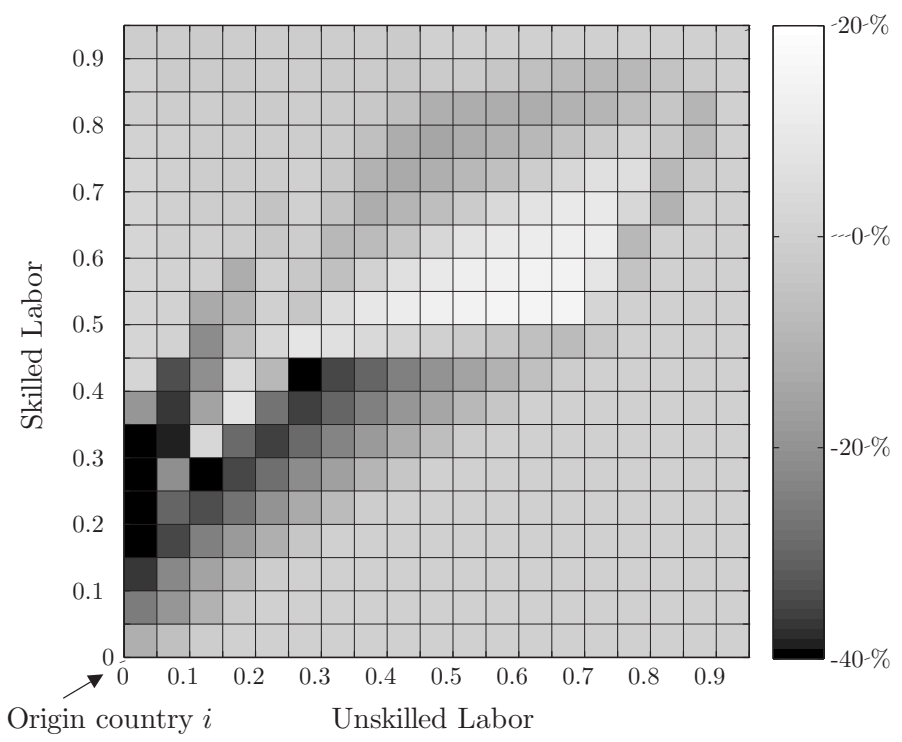

Figure 6: Difference in affiliate production with and without corporate taxation: Deduction method (difference between Figures 1 and 3)

Figures 5 and 6 provide a bird's eye view on the difference between the surfaces in Figures 2 and 1 and Figures 3 and 1, respectively. Obviously, corporate taxation exerts a negative impact on the foreign affiliate production mostly of relatively small exemption/credit economies. There, horizontal MNE activity is dominant in the equilibrium without taxation. Similarly, a small deduction country's MNE activity is most likely hurt by taxation. Especially, the latter is true for relatively (but not too) skilled labor abundant parent countries. 


\section{CESifo Working Paper Series}

(for full list see www.cesifo-group.de)

1709 Helge Berger and Stephan Danninger, The Employment Effects of Labor and Product Markets Deregulation and their Implications for Structural Reform, May 2006

1710 Michael Ehrmann and Marcel Fratzscher, Global Financial Transmission of Monetary Policy Shocks, May 2006

1711 Carsten Eckel and Hartmut Egger, Wage Bargaining and Multinational Firms in General Equilibrium, May 2006

1712 Mathias Hoffmann, Proprietary Income, Entrepreneurial Risk, and the Predictability of U.S. Stock Returns, May 2006

1713 Marc-Andreas Muendler and Sascha O. Becker, Margins of Multinational Labor Substitution, May 2006

1714 Surajeet Chakravarty and W. Bentley MacLeod, Construction Contracts (or "How to Get the Right Building at the Right Price?’), May 2006

1715 David Encaoua and Yassine Lefouili, Choosing Intellectual Protection: Imitation, Patent Strength and Licensing, May 2006

1716 Chris van Klaveren, Bernard van Praag and Henriette Maassen van den Brink, Empirical Estimation Results of a Collective Household Time Allocation Model, May 2006

1717 Paul De Grauwe and Agnieszka Markiewicz, Learning to Forecast the Exchange Rate: Two Competing Approaches, May 2006

1718 Sijbren Cnossen, Tobacco Taxation in the European Union, May 2006

1719 Marcel Gérard and Fernando Ruiz, Interjurisdictional Competition for Higher Education and Firms, May 2006

1720 Ronald McKinnon and Gunther Schnabl, China's Exchange Rate and International Adjustment in Wages, Prices, and Interest Rates: Japan Déjà Vu?, May 2006

1721 Paolo M. Panteghini, The Capital Structure of Multinational Companies under Tax Competition, May 2006

1722 Johannes Becker, Clemens Fuest and Thomas Hemmelgarn, Corporate Tax Reform and Foreign Direct Investment in Germany - Evidence from Firm-Level Data, May 2006

1723 Christian Kleiber, Martin Sexauer and Klaus Waelde, Bequests, Taxation and the Distribution of Wealth in a General Equilibrium Model, May 2006 
1724 Axel Dreher and Jan-Egbert Sturm, Do IMF and World Bank Influence Voting in the UN General Assembly?, May 2006

1725 Swapan K. Bhattacharya and Biswa N. Bhattacharyay, Prospects of Regional Cooperation in Trade, Investment and Finance in Asia: An Empirical Analysis on BIMSTEC Countries and Japan, May 2006

1726 Philippe Choné and Laurent Linnemer, Assessing Horizontal Mergers under Uncertain Efficiency Gains, May 2006

1727 Daniel Houser and Thomas Stratmann, Selling Favors in the Lab: Experiments on Campaign Finance Reform, May 2006

1728 E. Maarten Bosker, Steven Brakman, Harry Garretsen and Marc Schramm, A Century of Shocks: The Evolution of the German City Size Distribution 1925 - 1999, May 2006

1729 Clive Bell and Hans Gersbach, Growth and Enduring Epidemic Diseases, May 2006

1730 W. Bentley MacLeod, Reputations, Relationships and the Enforcement of Incomplete Contracts, May 2006

1731 Jan K. Brueckner and Ricardo Flores-Fillol, Airline Schedule Competition: ProductQuality Choice in a Duopoly Model, May 2006

1732 Kerstin Bernoth and Guntram B. Wolff, Fool the Markets? Creative Accounting, Fiscal Transparency and Sovereign Risk Premia, May 2006

1733 Emmanuelle Auriol and Pierre M. Picard, Government Outsourcing: Public Contracting with Private Monopoly, May 2006

1734 Guglielmo Maria Caporale and Luis A. Gil-Alana, Modelling Structural Breaks in the US, UK and Japanese Unemployment Rates, May 2006

1735 Emily J. Blanchard, Reevaluating the Role of Trade Agreements: Does Investment Globalization Make the WTO Obsolete?, May 2006

1736 Per Engström and Bertil Holmlund, Tax Evasion and Self-Employment in a High-Tax Country: Evidence from Sweden, May 2006

1737 Erkki Koskela and Mikko Puhakka, Cycles and Indeterminacy in Overlapping Generations Economies with Stone-Geary Preferences, May 2006

1738 Saku Aura and Thomas Davidoff, Supply Constraints and Housing Prices, May 2006

1739 Balázs Égert and Ronald MacDonald, Monetary Transmission Mechanism in Transition Economies: Surveying the Surveyable, June 2006

1740 Ben J. Heijdra and Ward E. Romp, Ageing and Growth in the Small Open Economy, June 2006 
1741 Robert Fenge and Volker Meier, Subsidies for Wages and Infrastructure: How to Restrain Undesired Immigration, June 2006

1742 Robert S. Chirinko and Debdulal Mallick, The Elasticity of Derived Demand, Factor Substitution and Product Demand: Corrections to Hicks' Formula and Marshall's Four Rules, June 2006

1743 Harry P. Bowen, Haris Munandar and Jean-Marie Viaene, Evidence and Implications of Zipf's Law for Integrated Economies, June 2006

1744 Markku Lanne and Helmut Luetkepohl, Identifying Monetary Policy Shocks via Changes in Volatility, June 2006

1745 Timo Trimborn, Karl-Josef Koch and Thomas M. Steger, Multi-Dimensional Transitional Dynamics: A Simple Numberical Procedure, June 2006

1746 Vivek H. Dehejia and Yiagadeesen Samy, Labor Standards and Economic Integration in the European Union: An Empirical Analysis, June 2006

1747 Carlo Altavilla and Paul De Grauwe, Forecasting and Combining Competing Models of Exchange Rate Determination, June 2006

1748 Olaf Posch and Klaus Waelde, Natural Volatility, Welfare and Taxation, June 2006

1749 Christian Holzner, Volker Meier and Martin Werding, Workfare, Monitoring, and Efficiency Wages, June 2006

1750 Steven Brakman, Harry Garretsen and Charles van Marrewijk, Agglomeration and Aid, June 2006

1751 Robert Fenge and Jakob von Weizsäcker, Mixing Bismarck and Child Pension Systems: An Optimum Taxation Approach, June 2006

1752 Helge Berger and Michael Neugart, Labor Courts, Nomination Bias, and Unemployment in Germany, June 2006

1753 Chris van Klaveren, Bernard van Praag and Henriette Maassen van den Brink, A Collective Household Model of Time Allocation - a Comparison of Native Dutch and Immigrant Households in the Netherlands, June 2006

1754 Marko Koethenbuerger, Ex-Post Redistribution in a Federation: Implications for Corrective Policy, July 2006

1755 Axel Dreher, Jan-Egbert Sturm and Heinrich Ursprung, The Impact of Globalization on the Composition of Government Expenditures: Evidence from Panel Data, July 2006

1756 Richard Schmidtke, Private Provision of a Complementary Public Good, July 2006

1757 J. Atsu Amegashie, Intentions and Social Interactions, July 2006 
1758 Alessandro Balestrino, Tax Avoidance, Endogenous Social Norms, and the Comparison Income Effect, July 2006

1759 Øystein Thøgersen, Intergenerational Risk Sharing by Means of Pay-as-you-go Programs - an Investigation of Alternative Mechanisms, July 2006

1760 Pascalis Raimondos-Møller and Alan D. Woodland, Steepest Ascent Tariff Reforms, July 2006

1761 Ronald MacDonald and Cezary Wojcik, Catching-up, Inflation Differentials and Credit Booms in a Heterogeneous Monetary Union: Some Implications for EMU and new EU Member States, July 2006

1762 Robert Dur, Status-Seeking in Criminal Subcultures and the Double Dividend of ZeroTolerance, July 2006

1763 Christa Hainz, Business Groups in Emerging Markets - Financial Control and Sequential Investment, July 2006

1764 Didier Laussel and Raymond Riezman, Fixed Transport Costs and International Trade, July 2006

1765 Rafael Lalive, How do Extended Benefits Affect Unemployment Duration? A Regression Discontinuity Approach, July 2006

1766 Eric Hillebrand, Gunther Schnabl and Yasemin Ulu, Japanese Foreign Exchange Intervention and the Yen/Dollar Exchange Rate: A Simultaneous Equations Approach Using Realized Volatility, July 2006

1767 Carsten Hefeker, EMU Enlargement, Policy Uncertainty and Economic Reforms, July 2006

1768 Giovanni Facchini and Anna Maria Mayda, Individual Attitudes towards Immigrants: Welfare-State Determinants across Countries, July 2006

1769 Maarten Bosker and Harry Garretsen, Geography Rules Too! Economic Development and the Geography of Institutions, July 2006

1770 M. Hashem Pesaran and Allan Timmermann, Testing Dependence among Serially Correlated Multi-category Variables, July 2006

1771 Juergen von Hagen and Haiping Zhang, Financial Liberalization in a Small Open Economy, August 2006

1772 Alessandro Cigno, Is there a Social Security Tax Wedge?, August 2006

1773 Peter Egger, Simon Loretz, Michael Pfaffermayr and Hannes Winner, Corporate Taxation and Multinational Activity, August 2006 